\title{
ס-Opioid Receptor Immunoreactivity: Distribution in Brainstem and Spinal Cord, and Relationship to Biogenic Amines and Enkephalin
}

\author{
Ulf Arvidsson, ${ }^{1}$ Robert J. Dado, ${ }^{1}$ Maureen Riedl, ${ }^{1}$ Jang-Hern Lee, ${ }^{1}$ Ping Y. Law, ${ }^{2}$ Horace H. Loh, ${ }^{2}$ Robert \\ Elde, ${ }^{1}$ and MartIn W. Wessendorf ${ }^{1}$ \\ 'Department of Cell Biology and Neuroanatomy and 'Department of Pharmacology, University of Minnesota, \\ Minneapolis, Minnesota 55455
}

We have recently developed antisera which recognize epitopes of the cloned $\delta$-opioid receptor (DOR; Dado et al., 1993). In the present report we have further characterized these antisera, and raised additional antisera in rats. We used these antisera to determine the distribution of DORlike immunoreactivity (-LI) in rat spinal cord and brainstem in relation to serotoninergic, noradrenergic, and enkephalinergic neurons. We found DOR-LI in fibers and varicosities distributed throughout the spinal cord gray matter, with highest densities in the superficial dorsal horn, in autonomic regions, around the central canal as well as in the ventral horn motor nuclei. In the brainstem a dense innervation of DOR-immunoreactive (-IR) fibers was found in several nuclei such as spinal trigeminal nuclei, midline raphe nuclei, parabrachial nuclei, periaqueductal gray matter (PAG), interpeduncular nucleus, and substantia nigra. A group of DOR-positive cells was seen in the laterodorsal tegmental nucleus. In addition, a few DOR-IR cell bodies were demonstrated in the parabrachial nuclei, interpeduncular nucleus, PAG, and superior and inferior colliculi as well as around the central canal in the spinal cord. All DORpositive cells showed a punctuate staining pattern within the cytoplasm of the cell body and in primary dendrites. No plasma membrane staining of cells or dendrites could be demonstrated using the DOR antisera.

Double-labeling experiments for DOR and 5-hydroxytryptamine (5HT, serotonin) revealed that some 5HT-IR neurons in the raphe complex were surrounded by DOR-IR fibers. In the spinal cord a high degree of coexistence was found between DOR and $5 \mathrm{HT}$ in nerve fibers and varicosities in the neuropil around the motoneurons and in lamina $V$ of the dorsal horn. In autonomic regions of the spinal cord, a low degree of colocalization was seen between DOR and 5HT; in the superficial dorsal horn no coexistence was found. Tyrosine hydroxylase (TH)-positive neurons in the brainstem (in the A5 area, locus coeruleus, and A7 area) were apposed by DOR-positive fibers. However, no coexistence could be seen between DOR and TH in any part of

\footnotetext{
Received Apr. 18, 1994; revised July 18, 1994; accepted July 27, 1994.

This study was supported by PHS Grants DA 05466, DA 06299, DA 07339 DA 01583, The Swedish Medical Research Council project 12X-6815, Stiftelsen Wenner-Gren Center, Minnesota Medical Foundation, and the Department of Cell Biology and Neuroanatomy.

Correspondence should be addressed to Ulf Arvidsson, Department of Cell Biology and Neuroanatomy, University of Minnesota, 321 Church Street SE, Minneapolis, MN 55455.

Copyright (C) 1995 Society for Neuroscience $0270-6474 / 95 / 151215-21 \$ 05.00 / 0$
}

the spinal cord. A close relation, but no coexistence, was observed between DOR- and enkephalin (ENK)-IR fibers in the spinal cord ventral horn; in the intermediolateral nucleus a low degree of colocalization was observed.

Thus, a $\delta$-opioid receptor may affect the activity of descending serotoninergic and noradrenergic neurons by means of modulating the release of neurotransmitters from afferents to these neurons. In addition, $\delta$-opioid receptors appear poised to modulate the release of 5HT (and coexisting peptides) from fibers in the spinal cord ventral horn and lamina V. However, these receptors appear unlikely to be importantly involved in modulation of the release of catecholamines or enkephalin in the spinal cord, or in modulation of the release of 5HT in the superficial dorsal horn. Finally, these data suggest that the antisera used preferentially localize a $\delta$-opioid receptor which is targeted to the axonal compartment of neurons, and thus this receptor most likely functions at a presynaptic site.

[Key words: 5-hydroxytryptamine, tyrosine hydroxylase, opioids, opioid receptor, coexistence, motoneurons, intermediolateral cell column, dorsal horn, raphe nuclei, noradrenergic nuclei, compartmentalization, presynaptic receptor]

The endogenous opioids enkephalin, dynorphin, and $\beta$-endorphin have been shown to be widely distributed in both the central and peripheral nervous systems (see reviews by Elde and Hökfelt, 1993, and Khachaturian et al., 1993), and are likely to act as neurotransmitters according to criteria defined by Scheller and Hall (1992). Because of their occurrence in a large number of discrete neural circuits, the opioids have been suggested to participate in regulation of nociception, respiration, cardiovascular function, gastrointestinal motility, mood, and affect (Pasternak, 1988). These suggestions are supported by the extensive literature on the pharmacological actions of the alkaloid opiate drugs. The effects of opioids are mediated via at least three major classes of receptors (defined with respect to selective binding characteristics), $\mu, \delta$, and $\kappa$ (see Corbett et al., 1993), and there may exist additional subtypes, so far not cloned, within each class (Fukuda et al., 1993; Nishi et al., 1993; Yasuda et al., 1993). The distribution of $\mu, \delta$, and $\kappa$ binding sites in the nervous system is different, although overlapping areas exist (see Mansour and Watson, 1993). A significant mismatch between opioid ligands and receptors has becn described (Hernkenham, 1987); however, the technical limitations of receptor autoradiography, for example, the inability to detect areas with low densities, must be considered. One example of each of the three 
receptor types has recently been cloned (Evans et al., 1992; Kieffer et al., 1992; Bzdega et al., 1993; Chen et al., 1993a,b; Meng et al., 1993; Minami et al., 1993; Thompson et al., 1993; Yasuda et al., 1993), and their structures predict they belong to the "seven-membrane-spanning" superfamily and are coupled to $\mathrm{G}$ proteins. Thus, it is now possible to determine more precisely the anatomical localization of opioid receptors using in situ hybridization and immunocytochemistry with antibodies directed against the predicted sequences of the receptors.

We have recently raised antisera against peptides which represent different regions of extracellular domains from mouse $\delta$-opioid receptor (DOR) and demonstrated their use in immunocytochemical studies (Dado et al., 1993). Morphological and physiological evidence suggests that the effects of opioids and opioid receptors are prominently involved in regulation of monoaminergic systems, in particular the serotoninergic system and the noradrenergic system (Elde et al., 1976; Atweh and $\mathrm{Ku}-$ har, 1977a,b; Levy and Proudfit, 1979; Charnay et al., 1982; Khachaturian and Watson, 1982; Basbaum and Fields, 1984; Illes, 1989; Pan et al., 1990; Collin et al., 1991; Arvidsson et al., 1992). We have therefore hypothesized the existence of three possible arrangements of opioid receptors with respect to the monoaminergic neurons which are affected by opioids: (1) a monoaminergic neuron expresses an opioid receptor which is targeted to its somatodendritic domain and functions in a postsynaptic manner; (2) a monoaminergic neuron expresses an opioid receptor which is targeted to its axonal domain and functions in a presynaptic manner; or (3) an opioid receptor is expressed by a neuron which provides afferent input to a monoaminergic neuron. We have also hypothesized that neurotransmission involving opioids is accomplished by the release of opioid peptides from nerve terminals which are in proximity to opioid receptors. In the present work we have tested these hypotheses with respect to the first of the cloned opioid receptors, DOR. In particular, we have further determined the selectivity of our previously reported (Dado et al., 1993) immunofluorescent approach to the study of this receptor. In the present work, we demonstrate that our antisera against DOR preferentially recognize a presynaptic receptor that is (1) in close proximity to enkephalinergic terminals, (2) localized in afferents to monoaminergic neurons in the brainstem, and (3) present in spinal terminals of $5 \mathrm{HT}$ neurons.

\section{Materials and Methods}

Animals, chemicals, and fixation. Adult male Sprague-Dawley rats (150-200 gm; Harlan, Madison, WI; $n=15$ ) were used in all experiments. The animals were deeply anesthetized with chloral hydrate (350 $\mathrm{mg} / \mathrm{kg}$ i.p.) and then subjected to a transcardial perfusion with calciumfree Tyrode's solution followed by a fixative containing $4 \%$ paraformaldehyde and $0.2 \%$ picric acid (variation of the formulation of Zamboni and De Martino, 1967) in $0.1 \mathrm{M}$ phosphate buffer, pII 6.9. After fixation, the perfusion continued with $500 \mathrm{ml}$ of $10 \%$ sucrose phosphate


amounts of glutaraldehyde $(0.1-3 \%)$ were added to this fixative. The spinal cord and brainstem were then rapidly dissected out and transferred to $10 \%$ suciuse buffer solution for $4 \mathrm{hr}$ before cutting.

Two animals received an injection of colchicine (Sigma, St. Louis, $\mathrm{MO} ; 120 \mu \mathrm{g}$ in $20 \mu \mathrm{l} \mathrm{NaCl}$, injected over $20 \mathrm{~min}$ ) into the lateral ventricle $24 \mathrm{hr}$ before death. In two other animals sciatic motoneurons were retrogradely labeled by dipping the cut nerve end into a $10 \%$ solution of Fluoro-Gold (in distilled $\mathrm{H}_{2} \mathrm{O}$ ) for $10 \mathrm{~min}$. All surgical procedures were performed under sodium pentobarbital $(40 \mathrm{mg} / \mathrm{kg}$ i.p.) anesthesia. Five days following application of the tracer these animals were killed. In order to better visualize 5HT neurons in the brainstem, three animals received an injection of the MAO inhibitor tranylcypromine (Sigma; $30 \mathrm{mg} / \mathrm{kg}$ i.p.) followed $30 \mathrm{~min}$ later by an injection of L-tryptophan (Sigma; $300 \mathrm{mg} / \mathrm{kg}$ i.p.). Two hours after the injection of the MAO inhibitor the animals were killed and perfused as described above.

Immunocytochemistry. Transverse (unless otherwise noted) 10-14 $\mu \mathrm{m}$ sections were cut on a cryostat, thaw mounted onto glass slides subbed with chrome alum gelatin, and processed for indirect immunofluorescence histochemistry (Coons, 1958; Hökfelt et al., 1973). In addition, tissue was also cut using a freezing microtome (Bausch and Lomb, Rochester, NY) at 40-50 $\mu \mathrm{m}$ and processed as free-floating sections. Rabbit $\delta$-opioid receptor (DOR) antisera raised against different portions of the predicted sequence of DOR were used (Evans et al., 1992; Kieffer et al., 1992). Antisera were raised against peptides corresponding to amino acids 3-17 (LVPSARAELQSSPLV, serum 442), 30-46 (AGANASGSPGARSASSL, serum 452), and 103-120 (PFQSAKYLMETWPFGELL, serum 461) (Fig. 1A; for further characterization see Dado et al., 1993). In addition, antisera were made in rats to the same peptides as used in rabbits to characterize further the specificity of the staining (see below).

Slide-mounted sections were incubated with primary antisera for 18 $24 \mathrm{hr}$ at $4^{\circ} \mathrm{C}$ (Table 1 ). The free-floating sections were incubated with primary antisera for $48-96 \mathrm{hr}$. In order to examine the relationship between DOR-IR structures and cells and fibers stained for 5HT, TH, or $\mathrm{ENK}$, and in a few cases for substance $\mathrm{P}$ and thyrotropin-releasing hormone, fluorescence double (Table 1; Wessendorf and Elde, 1985; Arvidsson et al., 1990) or triple labeling (Table 1; Staines et al., 1988; Wessendorf et al., 1990) was employed.

After incubation with the primary antiserum the sections were rinsed in phosphate-buffered saline (PBS) and incubated with secondary antisera ( $45 \mathrm{~min}$ at room temperature for cryostat sections; overnight at $4^{\circ} \mathrm{C}$ for free-floating sections; see Table 1). All antisera/antibodies used were diluted with $0.3 \%$ Triton X-100 in PBS (Hartman et al., 1972). After incubation with secondary antibodies the sections were rinsed several times in buffer. Sections single labeled using cyanine 3.18 were dehydrated, cleared, and mounted using DPX (Fluka, Ronkonkoma, NY). Sections that were single labeled using fluorescein isothiocyanate (FITC) and double- and triple-labeled sections were coverslipped with glycerol and PBS containing $0.1 \%$ p-phenylenediamine (Johnson and de C Nogueria Araujo, 1981; Platt and Michael, 1983). Sections were examined by conventional or confocal fluorescence microscopy. Micrographs were taken with black and white Tri-X film (Kodak, Rochester, NY).

Antisera and epitope mapping. Peptides representing amino acids 317 (101), 30-46 (102), and 103-120 (103; see specific amino acids above) from mouse DOR (Evans et al., 1992; Kieffer et al., 1992) were synthesized using an Applied Biosystems 432A solid-phase peptide synthesizer. The peptides were diluted with $0.1 \mathrm{M}$ Sorensons phosphate

\footnotetext{
Figure 1. A, Schematic diagram showing the putative transmembrane topology of the $\delta$-opioid receptor. The different regions of the molecule against which the antisera were raised are shown as black boxes labeled I-III. The sequences of the amino acids are also shown, as well as the number with which we refer to the different antisera. $B-H$. Images obtained by confocal microscopy of sections from rat spinal cord after incubation with $\delta$-opioid receptor antisera $(D O R) . B-D$, Three adjacent sections from the dorsal horn $(D H)$ showing labeling with rabbit DOR antisera 442 $(B), 452(C)$, and $461(D)$. Note similar distribution pattern but variation in intensity of labeling when used at the same dilution $(1: 400)$. $E$ and $F$, Elution and restaining of DOR-immunopositive cells in the laterodorsal tegmental nucleus $(L D T g)$. The section was first stained with DOR antiserum $442(E)$ and then eluted with potassium permanganate and sulfuric acid for $60 \mathrm{sec}$ (see Tramu et al., 1978), and then a secondary antisera was applied to test whether the elution of the primary antisera was complete. Finally the section was restained using DOR antiserum $461(F)$. Note that cells stained with DOR antiserum 442 are also stained with DOR antiserum 461 (arrows). $G$ and $H$, Two color fluorescence microscopy of a section from the spinal cord ventral horn motor nucleus incubated with rabbit antiserum 442 and rat antiserum 103 . Note presence of high degree of coexistence. Scale bars: $B-D, 100 \mu \mathrm{m} ; E$ and $F, 50 \mu \mathrm{m} ; G$ and $H, 50 \mu \mathrm{m}$.
} 
Table 1. Primary and secondary antisera used

\begin{tabular}{|c|c|c|c|c|}
\hline Antigen & Reference & Species & Dilution $^{b}$ & Secondary antisera \\
\hline \multicolumn{5}{|l|}{ Single labeling } \\
\hline DOR $442,452,461^{a}$ & Dado et al., 1993 & Rabbit & $1: 400$ & DoARbCy3 or DoARbFITC \\
\hline DOR101, 102, $103^{a}$ & Present study & Rat & $1: 100$ & DoARtCy3 or DoARtFITC \\
\hline $5 \mathrm{HT}$ & INCSTAR, Stillwater, MN & Goat & $1: 100$ & DoAGoCy 3 or DoAGoFITC \\
\hline $\mathrm{TH}$ & Pel-Freez, Rogers, AP & Sheep & $1: 100$ & DoAShCy3 or DoAShFITC \\
\hline ENK & Sera-Lab, Crewley Down, UK & Mouse & $1: 400$ & DoAMoCy3 or DoAMoFITC \\
\hline SP & Sera-Lab, Crewley Down, UK & Rat & $1: 100$ & DoARtCy 3 or DoARtFITC \\
\hline ppTRH & Carr et al., 1993 & Rabbit & $1: 400$ & DoARbCy 3 or DoARbFITC \\
\hline \multicolumn{5}{|l|}{ Double labeling } \\
\hline DOR442-DOR101 & & Rabbit-rat & $1: 400-1: 100$ & DoARbLRh-DoARtFIIC \\
\hline DOR442-DOR103 & & Rabbit-rat & $1: 400-1: 100$ & DoARbLRh-DoARtFITC \\
\hline DOR442 or $461-5 \mathrm{HT}$ & & Rabbit-goat & $1: 400-1: 100$ & DoARbLRh-DoAGoFITC \\
\hline DOR442 or $461-T H$ & & Rabbit-sheep & $1: 400-1: 100$ & DoARbFITC-DoAShLRh \\
\hline DOR442 or $461-E N K$ & & Rabbit-mouse & $1: 400-1: 400$ & DoARbFITC-DoAMoLRh \\
\hline DOR442 or $461-S P$ & & Rabbit-rat & $1: 400-1: 100$ & DoARbLRh-DoARtFITC \\
\hline DOR103-ppTRH & & Rat-rabbit & $1: 100-1: 400$ & DoARtFITC-DoARbLRh \\
\hline \multicolumn{5}{|l|}{ Triple labeling } \\
\hline DOR442 or $461-5 \mathrm{HT}-\mathrm{ENK}$ & & Rabbit-goat-mouse & $1: 400-1: 100-1: 400$ & DoARbCy5-DoAGoFITC-DoAMoLRh \\
\hline DOR442 or $461-5 \mathrm{HT}-\mathrm{TH}$ & & Rabbit-goat-sheep & $1: 400-1: 100-1: 100$ & DoARbCy5-DoAGoFITC-DoAShLRh \\
\hline DOR103-5HT-Fluoro-Goldd $d$ & & Rat-goat-rabbit & $1: 100-1: 100-1: 200$ & DoARtCy5-DoAGoLRh-DoARbFITC \\
\hline
\end{tabular}

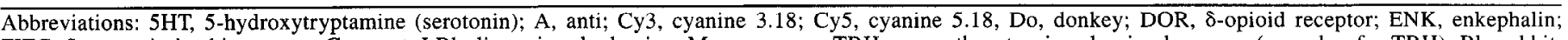

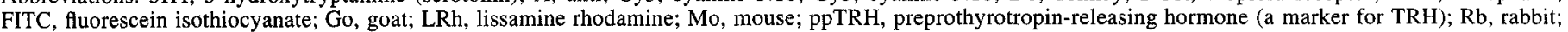
Rt, rat; Sh, sheep; SP, substance P; TH, tyrosine hydroxylase.

${ }^{a}$ For more information see Materials and Methods and Figure $1 \mathrm{~A}$.


antisera were used at a dilution between 1:60 and 1:200.

${ }^{c}$ All secondary antisera were purchased from Jackson ImmunoResearch, West Grove, PA.

¿ Purchased from Chemicon, Temecula, CA.

buffer to a concentration of $10 \mathrm{mg} / \mathrm{ml}$ and then conjugated to bovine thyroglobulin (Sigma; $40 \mathrm{mg} / \mathrm{ml}$ ) using $7 \%$ glutaraldehyde (Sigma; 30 $\mu \mathrm{l} / \mathrm{ml}$ ). The reaction mixture was then dialyzed exhaustively against PBS and diluted with $0.1 \mathrm{M}$ Sorensons phosphate buffer to an equivalent of $1 / 10$ from the original conjugation mixture. Peptide-thyroglobulin conjugates were emulsified with equal volumes of Freunds complete adjuvant (Difco, Detroit, MI) for initial immunizations. In subsequent immunizations Freunds incomplete adjuvant was used. Rats (male Sprague-Dawley, 350-400 gm; Harlan, Madison, WI) received an initial immunization of $0.2 \mathrm{ml}$ of conjugate/adjuvant mixture at a single site in the nape of the neck. Every 2 weeks animals were reimmunized with $0.1 \mathrm{ml}$ conjugate/adjuvant mixture injected at the same site. After three injections a small amount of blood was collected from the tail vein in order to screen the sera. If the immunoreactivity was judged to be adequate the rat was deeply anesthetized on the following day and exsanguinated through the jugular vein and by cardiac puncture. Between $13-18 \mathrm{ml}$ of blood were collected per rat by these means. The immunization procedure for rabbits is described in Dado et al. (1993) and Elde et al. (1976).

The peptide regions of the DOR molecule were chosen based upon their high antigenicity index (MACVECTOR) and their relative lack of homology to known sequences at the time these studies were initiated. (Homology was tested using the BLAST service of the National Library of Medicine.) From the more recent cloning of $\mu$ - and $\kappa$-opioid receptors it became apparent that peptides 103-120 have a high degree of homology to the two other opioid receptors, whereas peptides 3-17 and
30-46 have very low homology. Therefore, epitope mapping of antiserum 461 was done. Absorption controls were performed with peptides corresponding to amino acids 103-111 (PFQSAKYLM), 108-115 (KYLMETWP), and 112-120 (ETWPFGELL) of the DOR molecule. In addition, epitope mapping was also performed for antiserum 442, using peptides corresponding to residues 3-9 (LVPSARA), 7-12 (ARAELQ), and 10-17 (ELQSSPLV) of the DOR molecule. Concentrations of $10^{-10}-10^{-3} \mathrm{M}$ were used for absorption controls.

Confocal laser microscopy. For a detailed description of multicolor confocal laser microscopy see Brelje et al. (1993), Mesce et al. (1993), and Wessendorf and Brelje (1993). Briefly, specimens were examined with a Bio-Rad MRC-600 Confocal Imaging System (Bio-Rad Microscience Division, Cambridge, MA). As excitation source a krypton/ar gon ion laser (ILT Model 5470K, Ion Laser Technology, Salt Lake City, UT) with output at 488,568 , and $647 \mathrm{~nm}$ was used. FITC was imaged with $488 \mathrm{~nm}$ excitation and a 505-540 $\mathrm{nm}$ bandpass emission filter. Lissamine rhodamine B- and cyanine 3.18-labeled tissue were imaged with $568 \mathrm{~nm}$ excitation and a 598-621 nm bandpass emission filter. Tissue specimens labeled with cyanine 5.18 were imaged using a 647 $\mathrm{nm}$ excitation filter and a 664-696 nm bandpass emission filter.

The images shown are the results of projecting several optical sections taken at different micron intervals. All images were printed on Kodak XL700 Digital Color Printer (Rochester, NY).

Quantification and controls. The number of DOR-, 5HT-, and DOR/ $5 \mathrm{HT}$-immunoreactive varicosities in the lateral motor nucleus (lower lumbar level), sympathetic intermediolateral column (midthoracic lev-

Figure 2. Confocal microscopic images of sections from rat spinal cords after incubation with rabbit $\delta$-opioid receptor (DOR) antiserum 442 . $A$, Digital montage of lumbar ( $L u m b$ ) hemispinal cord. Note presence of dense innervation of DOR-like immunoreactivity in the superficial laminae of the dorsal horn, around the central canal as well as in the ventral horn. Part of the dorsal horn $(D H ; B)$, area around the central canal ( $C C$; $C$ ), and the ventral horn $(V H ; D)$ are shown at higher magnification in $B-D$, respectively. Note in $C$ the presence of small DOR-immunopositive cell bodies around the central canal (arrows). $E$ and $F$, In the intermediolateral cell column (IML; lower thoracic) and in the sacral parasympathetic nucleus $(S P N)$ a dense innervation of DOR-positive fibers and varicosities can be seen. Scale bars: $A, 500 \mu \mathrm{m} ; B, E$ and $F, 100 \mu \mathrm{m} ; C, 50 \mu \mathrm{m}$; $D, 40 \mu \mathrm{m}$. 

A
I: DOR 3-17:LVPSARAELQSSPLV
RAT-101, RABBIT-442
II: DOR 30-46:AGANASGSPGARSASSL
RAT-102, RABBIT-452
III: $D_{103-120}$ :PFQSAKYLMETWPFGELL RAT-103, RABBIT-461


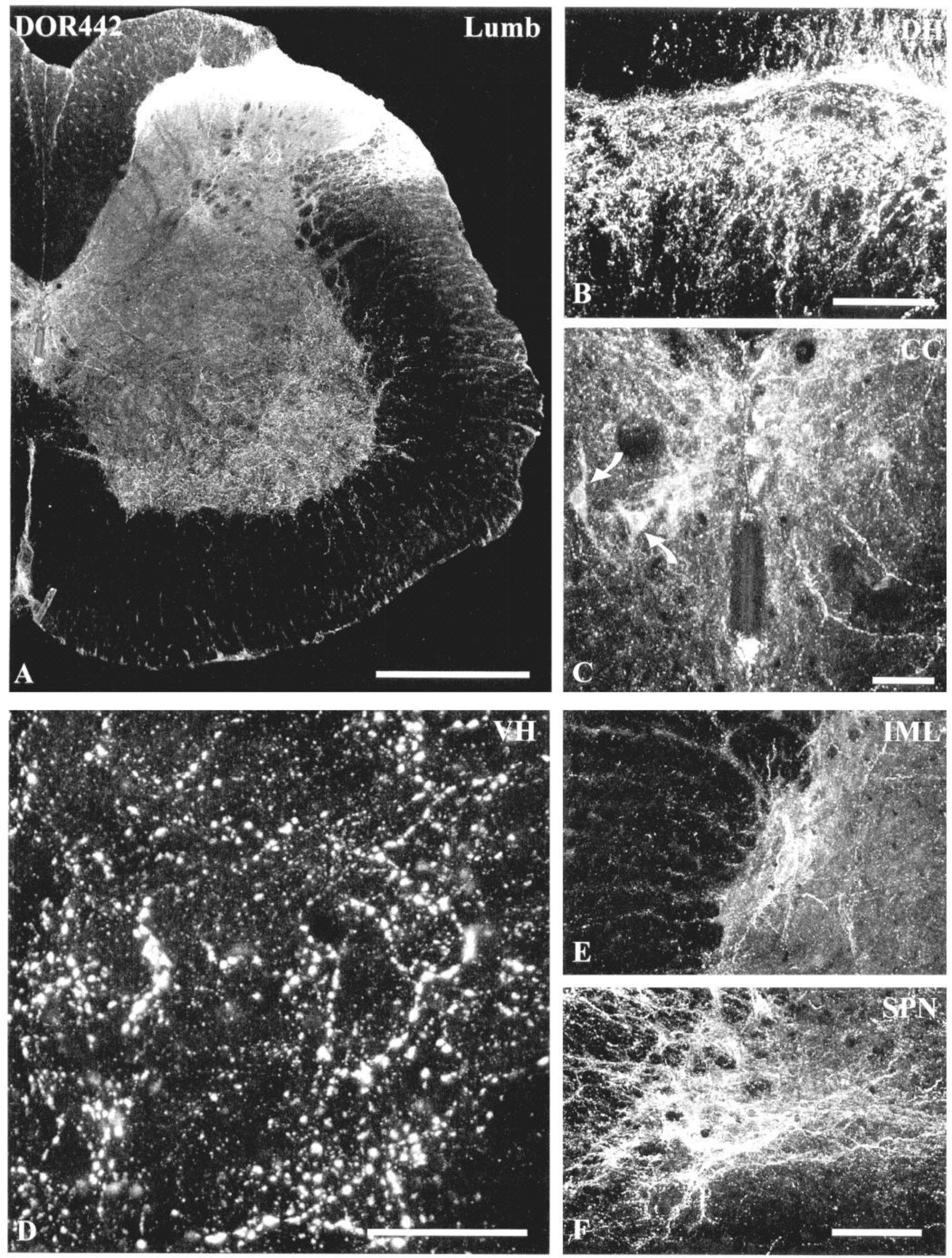
el), and superficial dorsal horn (lower lumbar level) were counted from scctions that had been double labeled with DOR442 and 5HT, and DOR461 and 5HT. All counts were done at the microscope with a $40 \times$ objective $(\mathrm{NA}=0.85$ ). The quantitative study used material from three animals and in each animal three sets of adjacent sections for DOR442 and 5HT, and DOR461 and 5HT, were analyzed.

Control sections were incubated with DOR antisera pretreated with homologous (against which the antisera were raised for DOR peptides) and/or heterologous peptides (other DOR peptides, enkephalin, calcitonin gene-related peptide, 5HT, and substance P). Absorption controls were done at concentrations of $10^{-10}-10^{-3} \mathrm{M}$. Cross-reactivity controls for both primary and secondary antisera were also done according to Wessendorf and Elde (1985) and Arvidsson et al. (1990). Adjacent sections from the dorsal root ganglion (containing DOR-positive neurons) and raphe nuclei (containing 5HT-positive neurons) were incubated with antisera to 5HT and DOR alone, in order to evaluate the specificity of the primary antisera.

To further characterize the antisera the elution/restaining technique of Tramu et al. (1978) was used. Cells labeled using DOR442 antiserum were photographed and then sections were immersed in a solution of potassium permanganate $\left(\mathrm{KMnO}_{4}\right)$ and sulfuric acid $\left(\mathrm{H}_{2} \mathrm{SO}_{4}\right)(2 \mathrm{ml}$ of $2.5 \% \mathrm{KMnO}_{4}$ and $2 \mathrm{ml}$ of $5 \% \mathrm{H}_{2} \mathrm{SO}_{4}$ in $50 \mathrm{ml}$ of distilled water) for $60 \mathrm{sec}$ to elute the antibodies. After several rinses in PBS the sections were incubated with FITC-conjugated secondary antibodies in order to evaluate the efficiency of the elution process. If no remaining fluorescence was observed the sections were incubated with the DOR461 antisera followed by a secondary antisenum in order to visualize the second antigen. The same areas as initially were photographed were again photographed.

In addition, double-labeling experiments using antisera raised in rat and antisera raised in rabbits recognizing different portions of DOR were also done.

\section{Results}

\section{Specificity of antisera}

In a previous report we briefly described the characterization of antisera raised against different portions of the extracellular domains of the mouse $\delta$-opioid receptor (see Fig. $1 A$; Dado et al., 1993). The antisera recognized three bands of appropriate molecular weight by Western blot analysis of membranes from NG108-15 cells and the same antisera were found to be useful also for immunohistochemical localization of the receptor in paraformaldehyde-fixed CNS tissue from rats (Dado et al., 1993). Different fixation procedures have subsequently' been tested; in unfixed sections as well as sections which were subsequently immersion fixed no clear labeling could be verified for any of the antisera; omitting Triton from primary and secondary antisera abolished the staining in most regions, but weak labeling remained in the dorsal horn (not shown); glutaraldehyde added to the fixative (up to $3.0 \%$ ) reduced the staining but DORimmunoreactive fibers and varicosities could still be seen, similar to paraformaldehyde-fixed tissue (not shown).

The three rabbit sera gave similar staining patterns in most regions in the spinal cord and brainstem; however, the intensities of staining were different, with DOR442>DOR461> DOR452 (compare staining from superficial dorsal horn in Fig. $1 B-D)$. Also, in a few areas the patterns of staining observed were not always identical. For instance, in contrast to the other rabbit sera, antiserum DOR452 did not appear to stain the lateral spinal nucleus (Fig. 1C).

The epitope mapping revealed that antiserum 461 was blocked by preincubation with amino acid residues $112-120$ (ETWPFGELL) and not by amino acid residues 103-111 (PFQSAKYLM) and 108-115 (KYLMETWP). This suggests that the antiserum 461 recognizes amino acid residues $116-120$ (FGELL). Staining using antiserum 442 was blocked by preincubation with the amino acid residues 10-17 (ELQSSPLV) but not by incubation with 3-9 (LVPSARA) or 7-12 (ARAELQ).
This suggests antiserum 442 recognizes the epitope 13-17 (SSPLV).

The distribution of DOR-like immunoreactivity often resembled that of substance $P$, and we therefore examined the possibility that our DOR antisera actually recognized substance $P$. Staining for DOR using any of the rabbit or rat antisera was unaffected by concentrations of substance $P$ from $10^{-10}$ to $10^{-5}$ $M$. Surprisingly, it was found that $10^{-4}-10^{-3} \mathrm{M}$ substance $P$ blocked staining obtained with all of the rabbit DOR antisera. However, using rat antisera against DOR (which appear to stain the same substance as the rabbit antisera; see below), this blocking was seen only in two of the four antisera tested. Moreover, in one of those two cases, labeling was blocked in the dorsal horn but not the remainder of the spinal cord. In addition, the concentration of substance $P$ required to block staining $\left(10^{-4}\right.$ $10^{-3} \mathrm{M}$ ) was several orders of magnitude higher than those required for the homologous peptides $\left(10^{-9}-10^{-8} \mathrm{M}\right)$. Finally, in preliminary ultrastructural studies, it was found that substance $\mathbf{P}$ and DOR labeled different intracellular structures. Together these observations suggest that it is unlikely that the DOR antisera recognize substance $P$.

The specificity of the DOR antisera was further characterized by testing whether antisera raised against different portions of the receptor sequence stained the same structures. In elutionrestaining experiments, coexistence between DOR442 and DOR461 could be demonstrated in cell bodies and a few fibers in the brainstem (Fig. $1 E, F$ ), although the elution procedure clearly reduced the intensity of immunostaining with the second set of antisera. In addition, antisera from rat and antisera from rabbit that were raised against different portions of DOR (Fig. $1 A$ ) frequently labeled the same varicosities. In the ventral horn, DOR442 stained 820 out of 821 DOR103-positive varicosities, with an additional 32 varicosities classified as ambiguous (see Fig. $1 G, H)$. Thus, although we have not been able to determine why substance $P$ blocks staining with DOR antisera, it appears likely that the DOR antisera recognize a bona fide $\delta$-opioid receptor.

\section{Distribution of DOR-like immunoreactivity in spinal cord and brainstem by single labeling}

The results below are based on observations with rabbit antisera DOR442 or DOR461 if not otherwise stated.

The distribution of DOR-LI was similar to that observed by Dado et al. (1993). In single-labeled sections DOR-LI could be found in varicosities throughout the gray matter in the spinal cord (Fig. 2A). Highest densities of DOR-LI were found in the superficial laminae of the dorsal horn including Lissauers tract (Fig. $2 B$ ), around the central canal (Fig. 2C), in ventral horn including the lateral and medial motor nuclei (Fig $2 D$ ) as well as in the autonomic regions of the cord, for example, in the intermediolateral nucleus, presumably around preganglionic sympathetic neurons (Fig. $2 E$ ), and in the sacral parasympathetic nucleus, presumably around preganglionic parasympathetic motoneurons (Fig. $2 F$ ). The lateral spinal nucleus (Giesler and Elde, 1985 ) also received a dense innervation of DOR-LI (see Fig. $2 A$ ). In the somatic motor nuclei, DOR-LI could sometimes be seen apposed to motoneurons retrogradely labeled from the sciatic nerve (see Fig. 7A). This type of close relation was also seen for neurons in the cremaster nucleus and in Onuf's nucleus (Fig. 3A-D). A few DOR-positive fibers were seen in Clark's column (not shown). No DOR-IR fibers were seen in other parts of the white matter except in the lateral funiculus at lower sacral 



Figure 3. Images obtained by laser confocal microscopy from the rat cremaster (Cremaster; $A, B)$ and Onuf's $(O n u f ; C, D)$ nuclei after incubation with rabbit $\delta$-opioid receptor $(D O R)$ antiserum 442 . The sections are from the rostral lumbar level (cremaster) and rostral sacral spinal cord (Onuf). Note dense accumulation of DOR-positive fibers in both nuclei. $B$ and $D$ are higher-magnification views of $A$ and $C$, respectively. Scale bars: $A$ and $C, 250 \mu \mathrm{m} ; B$ and $D, 50 \mu \mathrm{m}$.

levels (not shown). No clear difference in staining in any part of the spinal cord would be seen between different levels. DORIR cell bodies were sometimes seen around the central canal (see Fig. 2C). No neuronal cell bodies or glial-like elements positive for DOR-LI were seen in other parts of the spinal cord.

Studies of the brainstem revealed DOR-IR fibers in nucleus raphe pallidus, raphe obscurus (Fig. 4A), raphe magnus (Fig. $4 B$ ), and raphe dorsalis (Fig. $4 C$ ) as well as in raphe medianus (not shown). Serotoninergic nuclear groups lateral to the midline raphe complex, the lateral reticular and paragigantocellular reticular nuclei (Dahlström and Fuxe, 1964), received a relatively dense innervation of DOR-IR fibers and varicosities as well (not shown). Also, a dense innervation of DOR-positive fibers was seen in noradrenergic areas of the brainstem, for example, in area A5, locus coeruleus, and area A7 (Dahlström and Fuxe, 1964; see also below). Outside of the major monoaminergic nuclei, DOR-positive fibers and varicosities were also seen in other brainstem regions including, from caudal to rostral, spinal trigeminal nuclei, solitary tract and nuclei, hypoglossus nucleus, dorsal vagal nucleus, medullary reticular formation, inferior olive, ambiguus nucleus, vestibular nuclei, facial motor nucleus, abducens nucleus, tegmental nuclei, trigeminal motor nucleus, pontine reticular nuclei, parabrachial nuclei, locus coeruleus, periaqueductal gray matter, interpeduncular nucleus, red nucleus, and substantia nigra (not shown).

In a few areas of the brainstem DOR-positive cells could be seen. The most prominent group of cell bodies containing DORLI was seen just ventrolateral to the rostralmost part of the fourth ventricle, from bregma $-9.3 \mathrm{~mm}$ (according to Paxinos and Watson, 1986) extending cranially to bregma $-8.3 \mathrm{~mm}$, in the laterodorsal tegmental nuclei (Figs. $4 C, D ; 5 A$ ). These cells were moderately sized, ranging from 17 to $29 \mu \mathrm{m}$ [mean $=23 \mu \mathrm{m}$ $\left.\left(d_{\max }+d_{\min } / 2\right), \mathrm{SD}=3 \mu \mathrm{m}, n=37\right]$. DOR-immunopositive cells were also seen ventrolateral to the laterodorsal tegmental nuclei in the parabrachial nuclei (not shown). In addition, scattered, relatively small (several cells with $d_{\max }$ measured $<10 \mu \mathrm{m}$; see Fig. $5 B$ ) DOR-IR cells were also observed in the interpeduncular nucleus, PAG, and the nuclei of the inferior (Fig. 5B) and superior colliculi. Tissue from animals injected with colchicine into the lateral ventricle showed an increased number of DOR-IR cells in the brainstem, but only in the same nuclei containing DOR-immunopositive cells in untreated rats.

The DOR antisera stained small punctate structures in these cells and was distributed throughout the somatic cytoplasm and primary dendrites (Fig. 5A,B). We saw no clear examples of plasma membrane labeling at the level of neuronal cell bodies. 

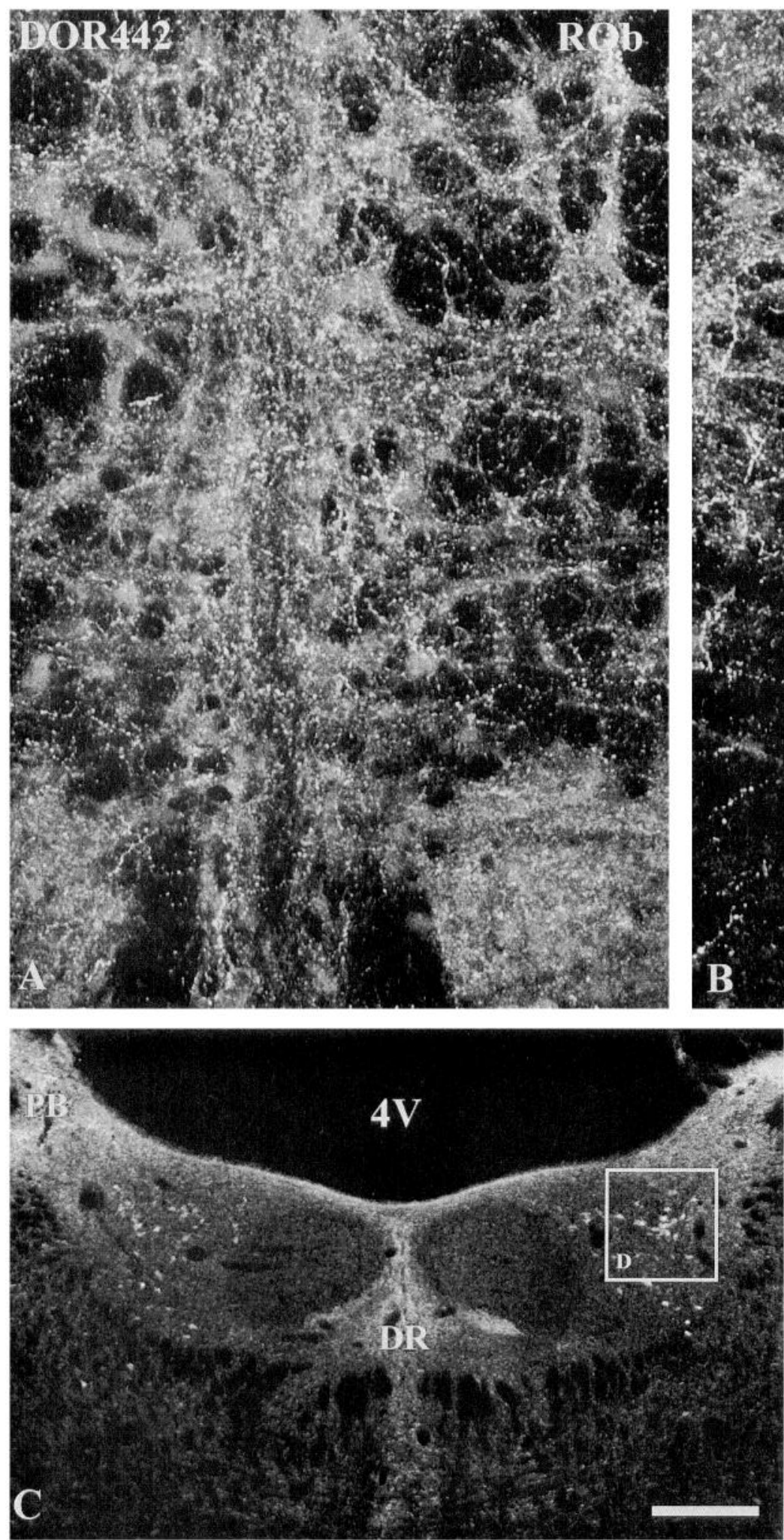


Figure 4. Confocal microscopic images from rat brainstem after incubation with rabbit $\delta$-opioid receptor $(D O R)$ antiserum $442 . A$ and $B$, Sections from the nuclei raphe obscurus $(R O b ; A)$ and raphe magnus $(R M g ; B)$. Note presence of DOR-positive fibers in both raphe nuclei. No immunoreactive cell bodies can be seen. $C, D$, Section from the brainstem at approximately a level of bregma -9 mm according to Paxinos and Watson (1986). Note group of DOR-immunopositive cell bodies in the laterodorsal tegmental nucleus $(L D T g)$. Also, DOR-immunoreactive fibers are seen in the dorsal raphe nucleus $(D R)$ and in the parabrachial nucleus $(P B) . D$ is a higher-magnification view of the framed area in $C$. $4 V$, fourth ventricle. Scale bars: $A, B$, and $D, 50 \mu \mathrm{m} ; C, 250 \mu \mathrm{m}$. 

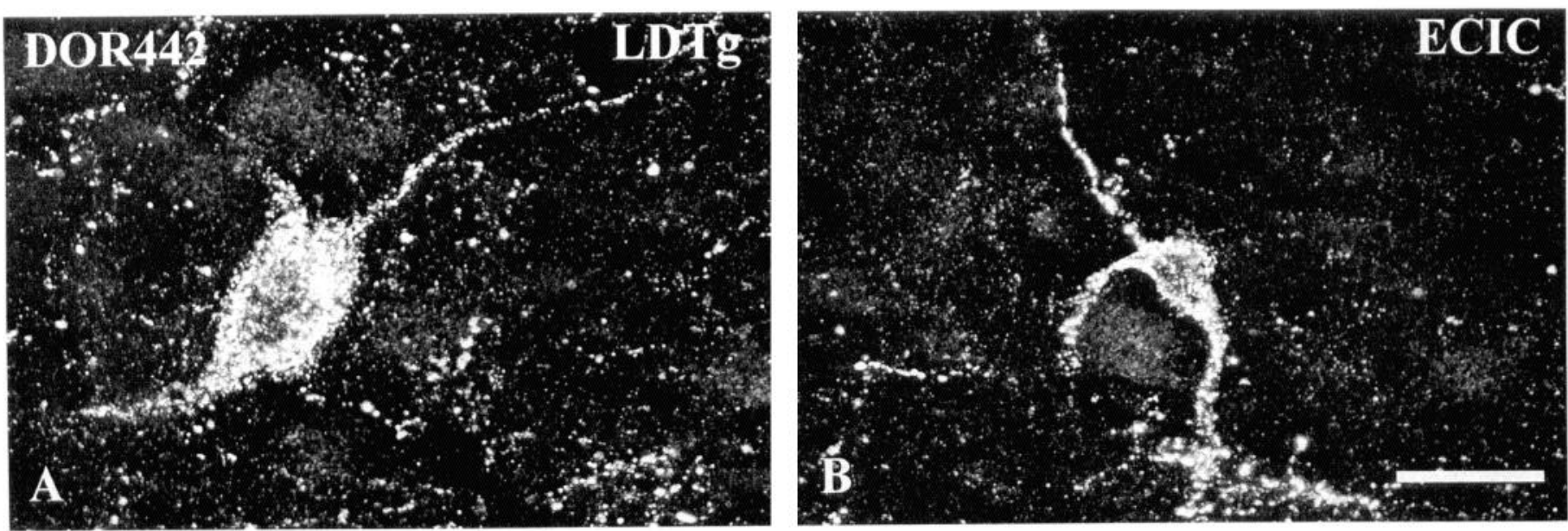

Figure 5. Confocal microscopic images of sections from the laterodorsal tegmental nucleus $(L D T g ; A)$ and external cortex of the inferior colliculus $(E C I C ; B)$ after labeling with rabbit $\delta$-opioid receptor $(D O R) 442$ antiserum. Note punctate DOR labeling in the cytoplasm and primary dendrites in both cells. No clear plasma cell membrane or dendritic membrane labeling can be seen. Both images are the results of projecting 11 optical sections taken at $0.4 \mu \mathrm{m}$ intervals. Scale bar, $20 \mu \mathrm{m}$.

A more detailed description of the overall distribution of DOR-LI in the rat brain is in progress (Arvidsson et al., unpublished observations).

\section{Double labeling: DOR with serotonin, tyrosine hydroxylase, or enkephalin}

In the ventral horn, a high degree of coexistence between DORand 5HT-LI was observed in the lateral and medial motor nuclei at all spinal cord levels (Fig. 6A-D). No significant difference in degrees of coexistence was observed between DOR442/5HT (5HT stained 666 out of 682 DOR442-IR varicosities, with an additional 12 cases ambiguous) and DOR461/5HT (5HT stained 602 varicosities out of 629 DOR461-IR varicosities, with an additional 18 cases ambiguous). Using triple-labeling procedure it was also possible to demonstrate that motoneurons retrogradely labeled from the sciatic nerve were apposed by 5HT-IR varicosities which also stained for DOR (see Fig. $7 A, B$ ). As expected, a high degree of coexistence was seen in the spinal cord motor nuclei when stained for DOR- and thyrotropin releasing hormone-LI, and DOR- and substance P-LI (not shown). However, in the cremaster motor nucleus coexistence of DOR-IR with 5HT-IR appeared to be less common (not illustrated). Little or no coexistence was seen in autonomic regions of the spinal cord [i.e., the intermediolateral nucleus (Fig. $6 E, F$ ) or the sacral parasympathetic nucleus].

In the dorsal horn, 5HT axons in the lateral reticulated area (lamina V) were frequently double labeled for DOR (Fig. 8C,D). However, among the 5HT-IR fibers of the superficial dorsal horn there was no coexistence between DOR- and 5HT-LI (Fig. $8 A, B)$.

The distribution of DOR-LI seen in double-labeled sections was overall similar to that found in single-labeled sections, suggesting that the double-labeling protocol did not interfere with staining. Control experiments suggested that the DOR antisera used did not recognize $5 \mathrm{HT}$ and that the $5 \mathrm{HT}$ antiserum did not recognize DOR (see Fig. $9 A-D$ ).

When staining for DOR and TH, the distributions of the two types of labeling overlapped. However, no coexistence of THand DOR-LI was observed in any portion of the spinal cord, including the dorsal horn (Fig. 10A,B), the intermediolateral nu- cleus (Fig. 10C,D), and the ventral horn motor nuclei (Fig. $10 E, F)$.

When staining for DOR and ENK, the distribution pattern seen for DOR-LI in the spinal cord complemented the distribution pattern for ENK-LI (see also Dado et al., 1993). However, no coexistence was observed in the spinal cord gray matter except for a few cases seen in the intermediolateral nucleus (Fig. $11 A-D$ ). In the brainstem a similar pattern was observed. A few DOR-IR fibers containing ENK-LI were seen in the lateral reticular and paragigantocellular reticular nuclei, raphe magnus area, and the superficial part of the inferior colliculus (not illustrated).

The relationship between DOR-IR varicosities and aminergic (5HT- or TH-IR) neuronal somata was also examined. In animals treated with MAO inhibitor and L-tryptophan, 5HT-IR neurons were seen throughout the raphe complex. Serotoninergic neurons in nucleus raphe pallidus and nucleus raphe obscurus were occasionally seen surrounded by DOR-IR terminals (Fig. 12A-D). DOR-positive fibers and varicosities were also apposed to $5 \mathrm{HT}$ neurons in nucleus raphe magnus (Fig. 12E-H) and in nucleus raphe dorsalis (not shown). No DOR-positive cell bodies or dendrites were seen in any part of the raphe nuclei complex.

Fibers containing both 5HT- and DOR-LI were seen in the midline raphe nuclei, lateral reticular and paragigantocellular reticular nuclei, hypoglossal nuclei, dorsal vagal motor nucleus, ambiguus nucleus, and trigeminal motor nucleus (not shown).

TH-positive neurons in the A5 group were sometimes closely apposed by fibers exhibiting DOR-LI (Fig. 13A-D). A less dense innervation by DOR-positive fibers and varicosities was seen around neurons in locus coeruleus (Fig. 13E-H) and around the TH-positive neurons in the A7 group (not shown).

No coexistence could be seen in fibers and varicosities in the brainstem when stained for TH- and DOR-LI besides a few fibers in nucleus raphe pallidus (not illustrated).

\section{Discussion}

There are six principle conclusions to this study. First, the antisera against DOR appear to recognize a bona fide $\delta$-opioid receptor. Second, the presence of DOR in axonal structures and its apparent absence from the plasma membrane at the level of 

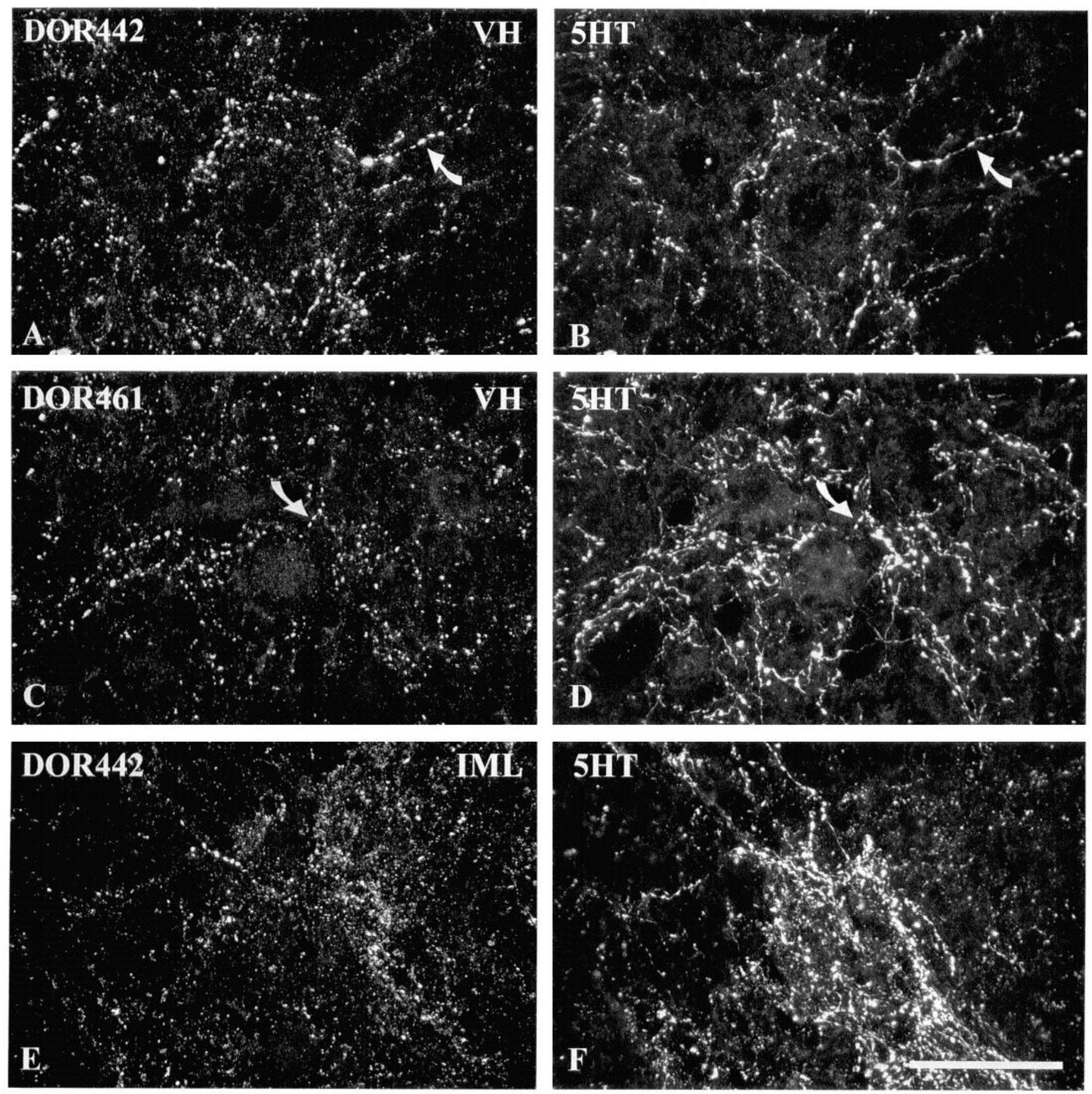

Figure 6. Images obtained by confocal microscopy of sections from the rat ventral horn $(V H ; A-D)$ and intermediolateral nucleus $(I M L ; E$, $F)$ after double labeling with rabbit $\delta$-opioid receptor $(D O R) 442$ and goat $5 \mathrm{HT}(A, B, E, F)$ and rabbit DOR 461 and goat $5 \mathrm{HT}(C, D)$ antisera. $A-$ $D$, A high degree of coexistence (arrows) can be seen in the ventral horn between 5HT and both of the DOR antisera (compare $A$ and $B$ with $C$ and $D$ ). $E$ and $F$, In the intermediolateral nucleus no clear DOR-immunoreactive fibers cocontaining 5HT-like immunoreactivity can be seen. Scale bar, $50 \mu \mathrm{m}$.

nerve cell bodies and primary dendrites suggests this receptor is directed to the axonal compartment and functions in a presynaptic manner. Third, DOR is prominent in nerve fibers and terminals in a variety of regions of the brainstem and spinal cord. Fourth, DOR exists on 5HT fibers in lamina V and in the ventral horn, but not on 5HT fibers in the superficial dorsal horn. Fifth, DOR exists on few, if any, catecholaminergic fibers or terminals in the spinal cord. Sixth, DOR appears poised to modulate afferent input to both serotoninergic and noradrenergic neurons in the brainstem.

\section{Characterization of DOR antisera}

Several lines of evidence argue that the antisera used in these studies recognize a bona fide $\delta$-opioid receptor (however, it can- 

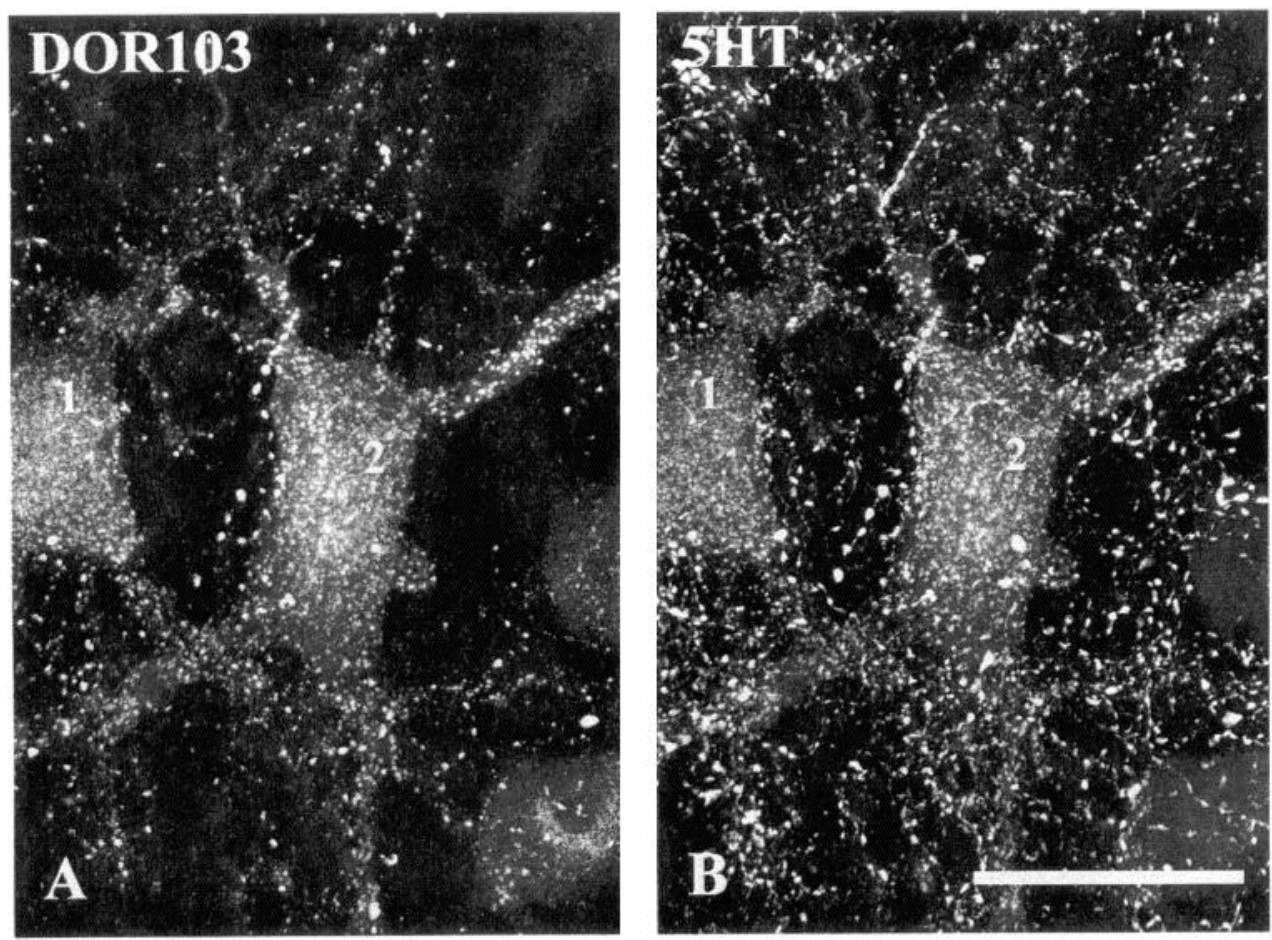

Figure 7. Images obtained by confocal microscopy of a section from the rat spinal cord ventral horn after triple labeling with rat $\delta$-opioid receptor (DOR) 103, goat 5HT, and rabbit Fluoro-Gold antisera. Motoneurons belonging to the sciatic motor pool were retrogradely labeled with Fluoro-Gold and visualized with a rabbit anti-Fluoro-Gold antiserum followed by FITCconjugated secondary antibodies. The distribution of Fluoro-Gold in the motoneurons (marked 1 and 2) is seen in the cytoplasm of the cell bodies and in the primary dendrites as a punctate labeling (shown in both $A$ and $B$ ). $A$, DOR immunoreactivity varicosities (visualized with cy5-conjugated secondary antibodies) can be seen in close apposition to motoneurons. $B$, Note serotonin-immunoreactive fibers and varicosities (detected with Lissaminerhodamine-conjugated secondary antibodies) that coexist with DOR in $A$. Scale bar, $50 \mu \mathrm{m}$.

not be excluded that the antisera also detect $\delta$-opioid receptor subtypes or other receptors not yet cloned). Many of the points relating to the specificity of the rabbit antisera have recently been described by Dado et al. (1993). To summarize, the antisera recognized bands having $\delta$-opioid receptor binding activity in Western blots from NG108-15 cells, the size of the bands that was recognized was consistent with the size predicted from DOR nucleotide sequence, labeling of a subset of primary afferent neurons by DOR antisera was confirmed by in situ hybridization, and incubation of the antisera with the peptides against which they were raised abolished staining (Dado et al., 1993). In homologous absorption controls the staining for all DOR antisera was blocked at concentrations as low as $10^{-9}-10^{-8} \mathrm{M}$. Surprisingly, in heterologous absorption controls with high concentrations $\left(10^{-4}-10^{-3} \mathrm{M}\right)$ of substance $\mathrm{P}$ it was found that some DOR staining was blocked. No other peptides tested (CGRP, ENK, and heterologous DOR peptides) or 5HT could block the DOR staining even at a concentration of $10^{-3} \mathrm{M}$. Moreover, we have observed a very high degree of coexistence between DOR (tested with all DOR antisera) and substance P (tested with both a polyclonal antisera and monoclonal antibodies) throughout the whole brain (U. Arvidsson, R. J. Dado, M. Riedl, J.-H. Lee, P. Y. Law, H. H. Loh, R. Elde, and M. W. Wessendorf, unpublished observations), indicating a close relationship between those two compounds, and suggesting possible cross-reactivity of the DOR antisera with substance P. At present it is unclear why substance $\mathrm{P}$ is able to block DOR staining but, rather than cross-reactivity, it also appears possible that high concentrations of substance $\mathrm{P}$ may interfere with binding of the antisera to the DOR molecule. The following points argue against true cross-reactivity between the rabbit DOR antisera and substance P. (1) Antisera were raised against three different regions of the DOR molecule with no homology to each other or to substance P. (2) The different rabbit anti-DOR antisera have a similar staining pattern in the brain and spinal cord. (3) Sections stained by combining rat and rabbit sera that were directed against different portions of DOR revealed almost complete double labeling. In addition, it was found using the elution/restaining technique that cells stained with rabbit antiserum 442 (against residues 3-17 of the receptor) were also immunoreactive using rabbit antiserum 461 (against residues 103-120). (4) There exist areas in which substance $P$ labeling without DOR, and DOR labeling without substance P, can be seen. (5) The rat antisera against DOR gave a staining pattern similar to the rabbit anti-DOR antisera, yet labeling was not consistently absorbed out even by $10^{-3} \mathrm{M}$ substance P. (6) At the electron microscopic level DOR and substance $\mathrm{P}$ stain different subcellular elements (Arvidsson, Dado, Riedl, Lee, Law, Loh, Elde, and Wessendorf, unpublished observations). Thus, from the evidence presented above it appears likely that the staining seen with the DOR antisera is specific.

The epitope mapping of the rabbit DOR antiserum 461, which was raised against amino acids 103-120 in the first extracellular loop of the DOR molecule, suggests that the antiserum recognizes amino acids 116-120 (FGELL). With the recent cloning of the $\mu$-and $\kappa$-opioid receptors, the first extracellular loop has been found to be highly conserved among the opioid receptors cloned so far, and thus contains the highest level of homology to the other opioid receptors (see Chen et al., 1993b). The only difference between FGELL in DOR and corresponding sequences in the $\mu$-and $\kappa$-opioid receptor is that EL has been substituted to TI in the $\mu$-opioid receptor and to DV in the $\kappa$-opioid receptor. Thus the epitope for antiserum DOR461 is less unique than that for DOR442 when compared to the other cloned opioid receptors. However, cross-reactivity seems unlikely since antiserum DOR461 does not stain cells transfected with constructs encoding the $\mu$ - and $\kappa$-opioid receptor, respectively (unpublished data).

\section{Compartmentalization of DOR}

The staining pattern of DOR appears to be axonal in nature, based on morphological considerations as well as the costaining 



Figure 8. Images obtained by confocal microscopy of sections from the rat dorsal horn $(D H ; A, B$; sectioned in the parasagittal plane) and lamina $\mathrm{V}$ of the dorsal horn $(\mathrm{Lam} . V ; C, D)$ after double labeling with rabbit $\delta$-opioid receptor $(D O R) 442$ and goat $5 \mathrm{HT}$ antisera. $A$ and $B$, No clear coexistence can be seen in the superficial laminae of the dorsal horn. $C$ and $D$, In lamina $\mathrm{V}$ of the lateral reticular area of the dorsal horn a few DOR-positive fibers cocontaining 5HT-like immunoreactivity can be observed. $g r$, gracile fasciculus. Scale bar, $50 \mu \mathrm{m}$.

of nerve fibers with antisera directed against transmitters known to be most prominent in axons. The present findings agree with previous reports on the presence of opioid receptors in axons. For example, axonal transport of opioid receptors occurs in the rat vagus nerve (Young et al., 1980) and dorsal root (Zajac et al., 1989; Laduron and Castel, 1990). In the present study we have been able to demonstrate that DOR is present in 5HT raphe neurons with a projection to the spinal cord ventral horn and that DOR is transported out into the axons of those neurons. No labeling is seen on somatic or dendritic membranes of the raphe neurons, consistent with DOR being restricted to axons.

A major question in receptor research concerns the mechanism by which receptors are targeted to their appropriate membrane domains. The present findings suggest that DOR is transported vesicularly since staining at the level of nerve cell bodies was not associated with the plasma membrane, but rather with small puncta (probably vesicles) within the cytoplasm. This hypothesis is further supported by a recent electron microscopic study where Pasquini et al. (1992) found that sites labeled with ${ }^{125}$ I-azido-DTLET (a $\delta$-opioid ligand) were frequently associated with the cytoplasm of axons rather than the plasma membrane. This is also in agreement with our preliminary studies at the electron microscopic level. Also, in an ongoing study (Dado et al., in preparation), transport of DOR seems to be most promi- nent in the anterograde direction, although a small component is retrogradely transported in the rat sciatic and sural nerve. Thus, the antisera used seem to recognize a $\delta$-opioid receptor that is mostly, if not exclusively, transported out into the axon, inserted into the plasma membrane at nerve terminals where it presumably functions as a presynaptic receptor. This pattern of compartmentalization is in striking contrast to that seen with the substance $\mathrm{P}$ receptor which seems to be a postsynaptic receptor in the central nervous system (Shigemoto et al., 1993; Liu et al., 1994; Vigna et al., 1994).

\section{Distribution of DOR in spinal cord and brainstem}

In the spinal cord, DOR-like immunoreactivity was present in fibers in the spinal gray, with highest densities in the superficial dorsal horn, in autonomic spinal regions, around the central canal, and in the ventral horn (see also Dado et al., 1993). In addition, a few DOR-positive cells were seen around the central canal.

Earlier studies in the spinal cord on $\delta$-opioid receptor distribution using radioligands such as ${ }^{3} \mathrm{H}-\left[\mathrm{D}-\mathrm{Ala}^{2}, \mathrm{D}-\mathrm{Leu}^{5}\right]$ enkephalin (DADLE) in combination with [Tyr-D-Ala-Gly-MePhe-Gly-ol] (DAGO; used to displace $\mu$ binding), ${ }^{3} \mathrm{H}$-[Tyr-D-Thr-Gly-PheLeu-Thr] (DTLET), ${ }^{3} \mathrm{H}-\left[\mathrm{D}-\mathrm{Pen}^{2}\right.$, D-Pen ${ }^{5}$ enkephalin (DPDPE), and ${ }^{3} \mathrm{H}-[$ Tyr-D-Ser $(O$-tert-butyl)-Gly-Phe-Leu-Thr] (DSTBU- 



Figure 9. Confocal microscopic images of adjacent sections from the rat lumbar dorsal root ganglion $(D R G ; A, B)$ and dorsal raphe nucleus $(D R$; $C, D)$ after incubation with rabbit $\delta$-opioid receptor $(D O R)$ antiserum $442(A, C)$ and goat $5 \mathrm{HT}$ antiserum $(B, D) . A$ and $B$, DOR-immunoreactive cell bodies can be seen in the dorsal root ganglion, whereas no staining can be seen with the 5HT antiserum, indicating that the 5HT antiserum does not recognize a DOR epitope. $C$ and $D$, Note the presence of DOR-immunoreactive fibers (but no cells) in dorsal raphe nucleus, whereas the $5 \mathrm{HT}$ antiserum stains both fibers and cells. Thus, the DOR antiserum does not recognize a $5 \mathrm{HT}$ epitope. Scale bars: $A$ and $B, 50 \mu \mathrm{m} ; C$ and $C$, $40 \mu \mathrm{m}$. 

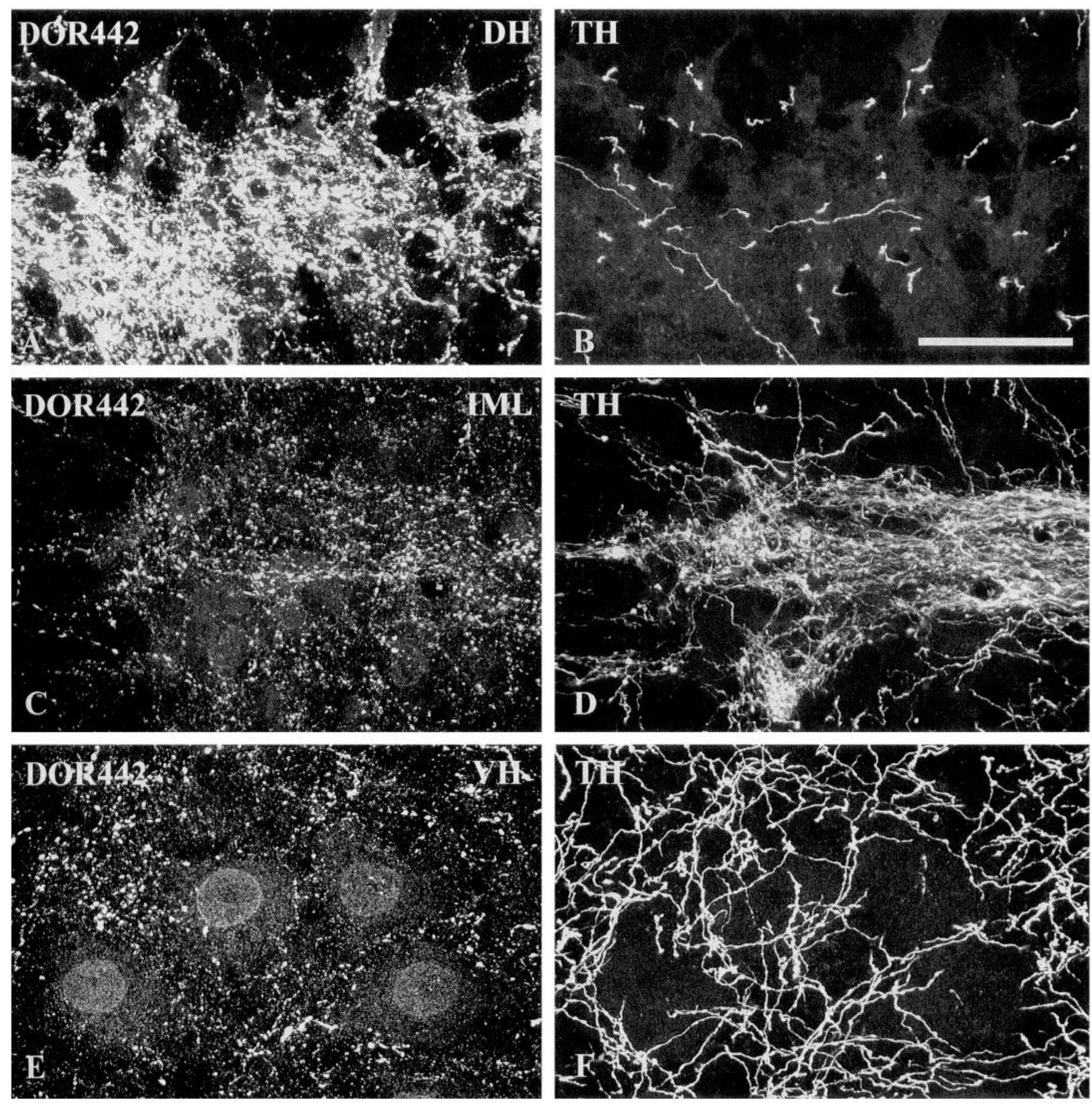

Figure 10. Images obtained by confocal microscopy of sections from the rat dorsal horn $(D H ; A, B)$, intermediolateral nucleus $(I M L ; C, D)$, and ventral horn $(V H ; E, F)$ after double labeling with rabbit $\delta$-opioid receptor $(D O R) 442$ and sheep tyrosine hydroxylase $(T H)$ antisera. $A$ and $B$, No coexistence between DOR- and TH-positive fibers and varicosities can be found in the dorsal horn. $C-F$, A dense innervation of TH-immunoreactive fibers and varicosities is found in both the intermediolateral nucleus as well as in the ventral horn motor nucleus, but no unequivocal examples of coexistence can be seen. Scale bar, $50 \mu \mathrm{m}$.

LET) have found the highest densities of labeling in the superficial dorsal horn (see, e.g., Gouarderes et al., 1985; Morris and Herz, 1987; Zajac et al., 1988; Delay-Goyet et al., 1990; Besse et al., 1991; Stevens et al., 1991). Using a selective $\delta$-opioid receptor ligand, ${ }^{125} \mathrm{I}-\left[\mathrm{D}-\mathrm{Ala}^{2}\right]$ deltophin-I, heavy labeling was seen in the superficial dorsal horn (Gouarderes et al., 1993). However, a relatively strong labeling was also observed in the ventral horn (between $50-70 \%$ of the density observed in the substantia gelatinosa; Gouarderes et al., 1993). The presence of $\delta$-opioid receptor binding in the ventral horn is in agreement with our data and suggests that ${ }^{125} \mathrm{I}-\left[\mathrm{D}-\mathrm{Ala}^{2}\right]$ deltophin-I and our antisera recognize the same receptor. However, it cannot be excluded that the antibodies used here detect a different subtype of the $\delta$ opioid receptor. In fact, pharmacological evidence for two sub- 

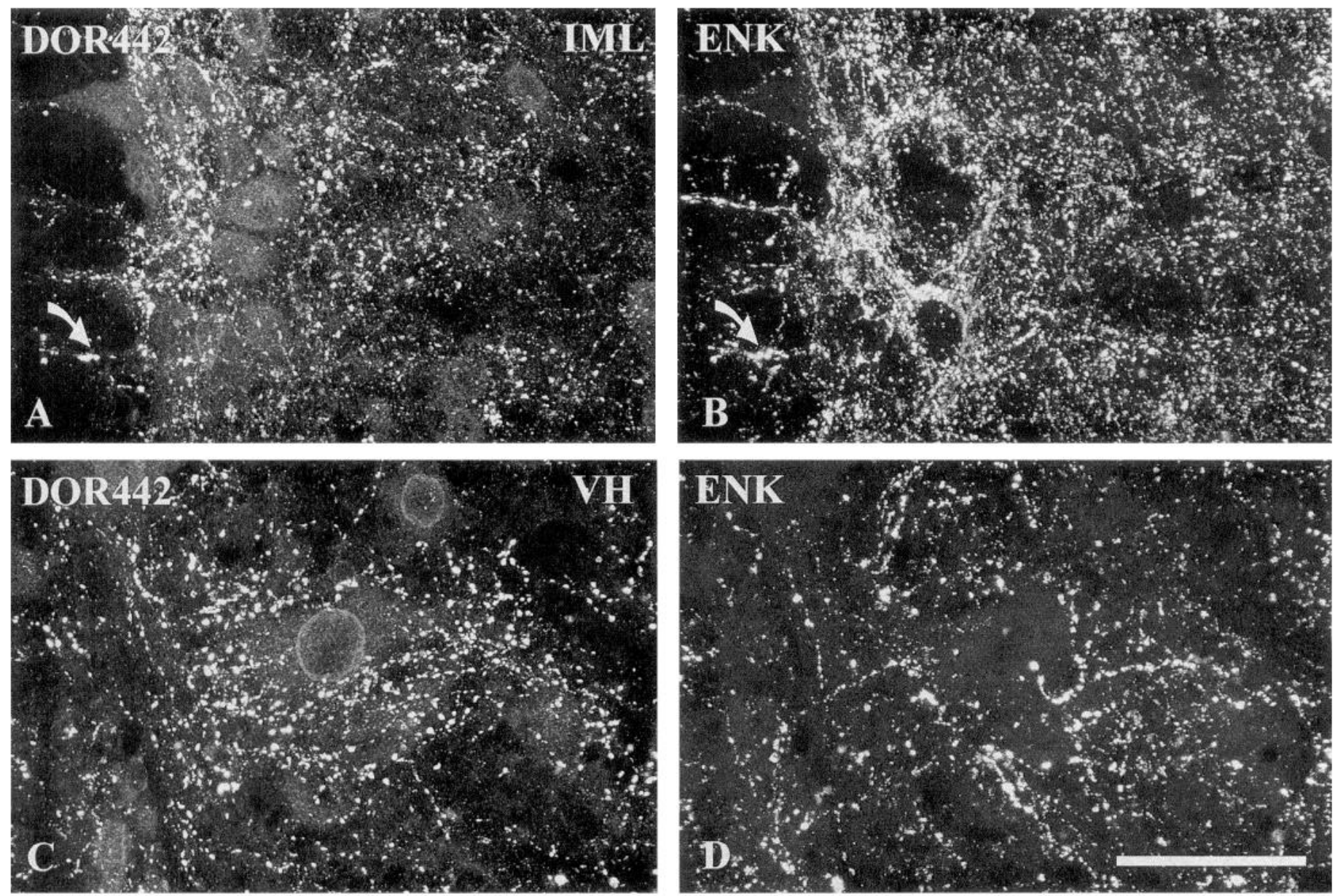

Figure 11. Images obtained by confocal microscopy of sections from the rat intermediolateral nucleus $(I M L ; A, B)$ and ventral horn $(V H ; C, D)$ after double labeling with rabbit $\delta$-opioid receptor $(D O R) 442$ antiserum and mouse enkephalin $(E N K)$ antibodies. $A$ and $B$, Most of the DORimmunopositive fibers and varicosities in the intermediolateral nucleus are clearly separated from the enkephalinergic innervation. However, a few terminals exhibit immunofluorescence for both compounds (arrows). $C$ and $D$, A dense innervation of ENK-positive fibers is also seen in the ventral horn motor nucleus $(D)$; however, no unambiguous coexistence between DOR and ENK can be found. Scale bar, $50 \mu \mathrm{m}$.

types of $\delta$-opioid receptors exists $\left(\delta_{1}\right.$ and $\delta_{2}$; see Sofuoglu et al., 1991).

In the brainstem, DOR-immunoreactive fibers were encountered in a number of areas, including sensory, motor, autonomic, and reticular areas. DOR-positive cells were seen in only a few areas, for example, parabrachial nuclei, interpeduncular nucleus, PAG, the superior and inferior colliculi, and the laterodorsal tegmental nucleus. The group of DOR-positive cells found in laterodorsal tegmental nucleus may possibly include some cholinergic cells with ascending projections (Satoh and Fibiger, 1986). A subpopulation of these laterodorsal tegmental neurons has also been found to contain substance P (see Vincent et al., 1983).

The distribution of $\delta$-opioid binding sites in the brainstem appears not to have been examined as frequently as in the spinal cord, telencephalon, or diencephalon. However, there are reports in the literature that $\delta$-opioid ligands label the brainstem lightly at most sites with a higher density in areas such as nucleus solitarii tractus, nucleus ambiguus, locus coeruleus, dorsal raphe nucleus, superior and inferior colliculi, central gray, and interpeduncular nucleus (Atweh and Kuhar, 1977b; Waksman et al., 1986; Mansour et al., 1987; Sharif and Hughes, 1989; Delay-Goyet et al., 1990; Gouarderes et al., 1993). In the present study we found DOR-positive fibers in all nuclei where $\delta$-opioid binding sites have been demonstrated earlier. In addition, scattered DOR-immunoreactive fibers were found in areas where bindings sites have not been demonstrated previously, such as nucleus raphe pallidus and nucleus raphe obscurus. These findings suggest that DORs may be distributed in the brainstem more widely than previously has been thought. Another possibility that has to be considered is that this discrepancy reflects cross-reactivity of our antisera to other molecules. However, given the evidence for the specificity of the antisera (see above) and the inherently higher resolution of immunocytochemistry, it appears more likely that the discrepancy is a result of the technical limitations of autoradiography and/or oversight by previous investigators.

Using in situ hybridization technique it is possible to localize the parent cells expressing $\delta$-opioid receptor mRNAs, but no detailed description of the brainstem and spinal cord has yet been reported (Bzdega et al., 1993; Mansour et al., 1993). In preliminary studies we have observed regions in the brainstem with cellular expression of DOR mRNA including the caudal raphe nuclei (Arvidsson et al., unpublished). These findings are consistent with some 5HT neurons expressing DOR MRNA. 

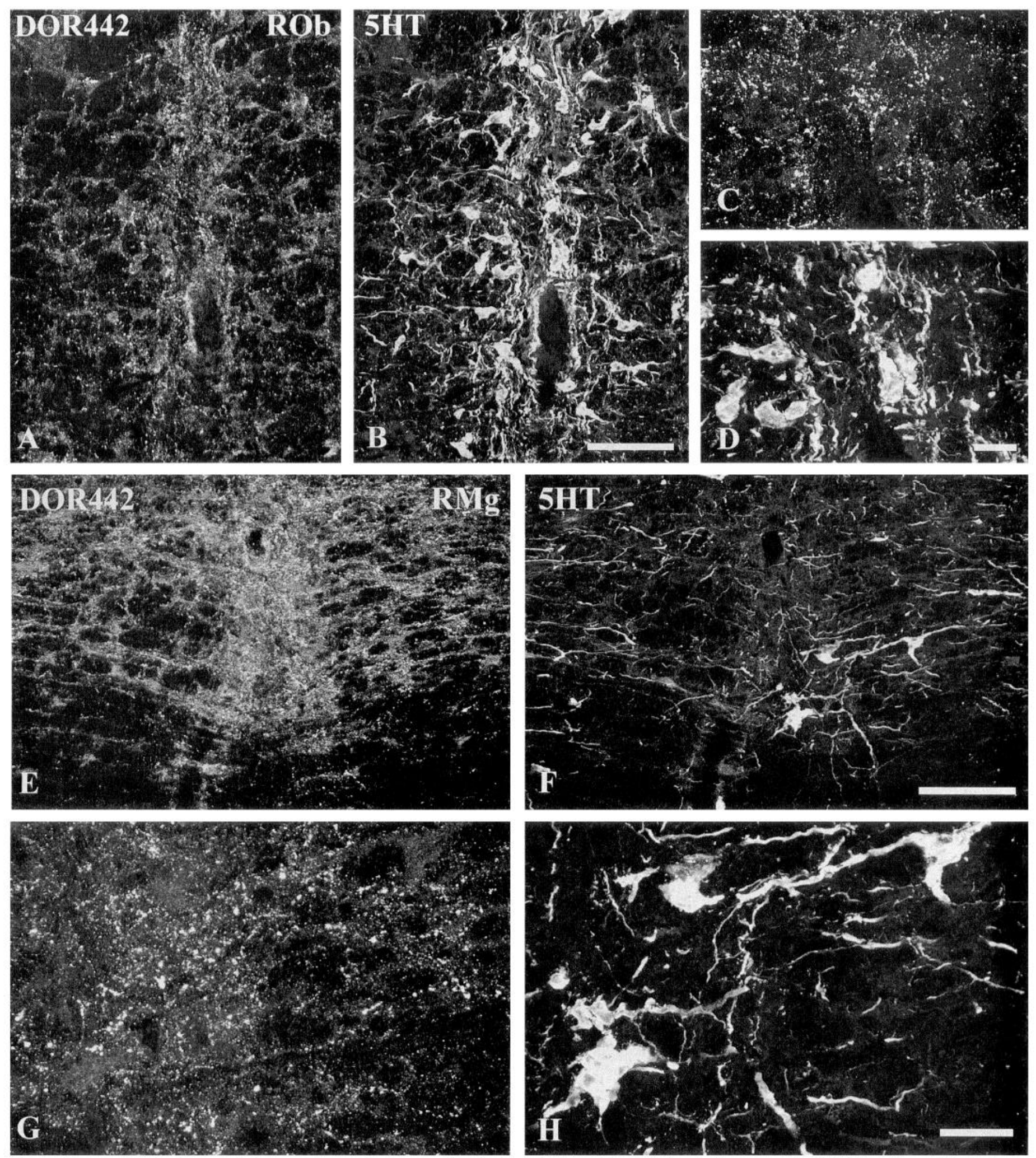

Figure 12. Confocal microscopic images from rat brainstem after double labeling with rabbit $\delta$-opioid receptor $(D O R) 442$ and goat $5 \mathrm{HT}$ antisera. $A-D$, Section from the nucleus raphe obscurus $(R O b)$. Note the presence of a relative dense innervation of DOR-positive fibers and varicosities among the serotonin-positive neurons. The close vicinity of DOR-immunoreactive terminals to the serotoninergic neurons is shown at higher magnification in $C$ and $D$. E-H, A similar arrangement between DOR and serotonin is also present in the nucleus raphe magnus $(R M g)$. $G$ and $H$ are higher-magnification views of $E$ and $F$, respectively. Scale bars: $A$ and $B, E$ and $F, 100 \mu \mathrm{m} ; C$ and $D, G$ and $H, 25 \mu \mathrm{m}$. 
Distribution of DOR with respect to biogenic amines and enkephalin

A schematic representation of the distribution of DOR in relation to enkephalin and biogenic amines in brainstem and spinal cord is given in Figure 14. A high degree of coexistence between DOR and $5 \mathrm{HT}$ was found around the motoneurons in the ventral horn, where most, if not all, DOR-IR varicosities were double labeled for $5 \mathrm{HT}$. In contrast, only scarce coexistence was seen in spinal autonomic areas, for example, in the intermediolateral nucleus and in the sacral parasympathetic nucleus. The latter suggests that DORs on 5HT terminals may not be involved in mediating the autonomic effects of opiates. In support of the latter idea, no coexistence of DOR-IR and 5HT-IR could be identified in the superficial dorsal horn. Thus we find no morphological evidence that DORs act directly on serotoninergic terminals in the superficial dorsal horn. However, it appears possible that DOR modulates serotonin release in deeper portions of the dorsal horn or that the effects of opioids on 5HT release are mediated by other types or subtypes of opioid receptors. However, double-labeled fibers were seen in the lateral reticulated area. Its presence in the lateral reticulated area is of particular interest since cells in that region have been reported to be nociceptive (Menetrey et al., 1977).

What is the functional significance of DOR on 5HT terminals in the spinal cord horn? Opioid receptors appear to have developmental effects on 5HT neurons (Davila-Garcia and Azmitia, 1989) and biochemical and behavioral evidence for an interaction between opioid receptors and 5HT cells has been reported in the spinal ventral horn as well as in other regions of the CNS (Brase, 1979; Parenti et al., 1983). The presence of DOR labeling on 5HT axons in the spinal cord is of interest, since opiates have been reported to increase the release of $5 \mathrm{HT}$ in both the dorsal and ventral horn (Bineau-Thurotte et al., 1984). Opioid receptors appear to modulate the release of a variety of neurotransmitters presynaptically, in some cases resulting in presynaptic inhibition of release and, in others, in presynaptic facilitation (Starke, 1981; for more references see Mulder and Schoffelmeer, 1993). However, $\delta$-opioid receptors have been reported to facilitate release of dopamine in striatum (Lubetzki et al., 1982; Petit et al., 1986). Monrue et al. (1986) have demonstrated that the opiate agonist DADLE (a ligand for both $\delta$ and $\mu$-opioid receptors) depressed stimulated release of $5 \mathrm{HT}$ from whole spinal cord synaptosomal preparations. Presently it is not known whether the $\delta$-opioid receptor on 5HT terminals in the spinal cord subserves presynaptic inhibition or presynaptic facilitation. 5HT has been reported to inhibit nociceptive neurons in lamina V (see Willcockson et al., 1984). Thus, presynaptic facilitation of $5 \mathrm{HT}$ release by opioids might result in antinociception.

As mentioned above, the motor nuclei in the spinal cord are innervated by a dense network of varicosities double labeled for 5HT and DOR. In the same region are found many varicosities immunoreactive for Leu- and/or Met-enkephalin. The latter opioids have their highest affinity for the $\delta$-opioid receptor (Corbett et al., 1993). Thus an endogenous ligand for activation of the $\delta$-opioid receptor that occurs on 5HT terminals in the ventral horn is present in close proximity to the receptor itself. It is unclear whether interactions between enkephalin terminals and DORs could be mediated synaptically, since electron microscopic studies of the ventral horn have not reported axoaxonic synapses onto 5HT terminals (Wang et al., 1989). A similar close but nonsynaptic relationship was noted in the case of the relationship of enkephalin to DOR-positive primary afferent terminals in the dorsal horn (Dado et al., 1993). However, it has been proposed that some ncurotransmitters may act on receptors distant from their release sites (for more references see Fuxe and Agnati, 1991).

It is also possible that the $\delta$-opioid receptor functions as an autoreceptor. ENK-IR varicosities were occasionally double labeled for DOR in the intermediolateral nucleus (Fig. 11A,B) as well as in some areas in the brainstem (lateral reticular and paragigantocellular reticular nuclei, raphe magnus area, and in the superficial part of the inferior colliculus), suggesting that DORs may modulate the release of enkephalin from these terminals. These findings are consistent with the observation that $\mathrm{K}^{+}$evoked release of enkephalin from rat spinal cord slices has been found to be reduced, even in the presence of tetrodotoxin, by $\delta$ (DTLET) and $\mu$ - (DAGO) opioid agonists (Collin et al., 1991). Another potential site at which DOR may act as an autoreceptor is on 5HT terminals in the ventral horn. Coexistence of 5HT and enkephalin has been observed in nucleus raphe pallidus and nucleus raphe obscurus, which project to the spinal ventral horn (Millhorn et al., 1989). Although coexistence of 5HT and enkephalin appears to be rare in the rat ventral horn (Wessendorf et al., 1990), their coexistence has been reported in cat and monkey (Tashiro et al., 1988; Arvidsson et al., 1992) and it is possible that low levels of enkephalin are present in DOR-IR 5HT fibers in rat as well. Thus enkephalin may conceivably modulate its own release via activation of DOR on 5HT terminals in the ventral horn.

In contrast to 5HT fibers, DOR were not found on fibers stained for $\mathrm{TH}$ (with the exception of a few fibers in nucleus raphe pallidus). Interfering with noradrenergic neurotransmission decreases the potency of opiates (for references see Illes, 1989 ), suggesting the presence of opioid receptors on noradrenergic cells or their spinal processes. By using selective opioid receptor agonists and antagonists it has been demonstrated that depolarization-induced noradrenaline release from rat cortical slices is inhibited by opioids only via activation of $\mu$ receptors (see Hagan and Hughes, 1984; Werling et al., 1987). Thus, $\delta$-opioid receptor-selective agonists such as DPDPE and DSTBULET had no effect on noradrenaline release. This inhibition of depolarization-induced release of noradrenaline occurs not only in cortcx but also in other brain areas (for references see Mulder and Schoffelmeer, 1993). Since no coexistence was found between DOR and TH it thus appears unlikely that the actions of opiates on spinal cord and brainstem noradrenergic terminals are mediated via activation of DOR.

In the brainstem DOR-IR varicosities were seen in close proximity to serotoninergic neurons in pons/medulla and midbrain. In addition, DOR-IR varicosities were also found around TH-positive neurons in both the lateral tegmental nuclei (A5), locus coeruleus, and in area A7. These observations suggest that afferent input to these regions may be modulated by DOR.

In electrophysiological studies of 5HT neurons in nucleus raphe magnus, inhibitory postsynaptic potentials mediated by GABA have been reported to be decreased by activation of opioid receptors (Pan et al., 1990, 1993). Although $\mu$-rather than $\delta$-opioid receptors mediated the observed effects (Pan et al., 1990), the present findings suggest that opioid receptors are present on afferents to serotoninergic cells. Microinjection of morphine or opioid peptides into nucleus raphe magnus 

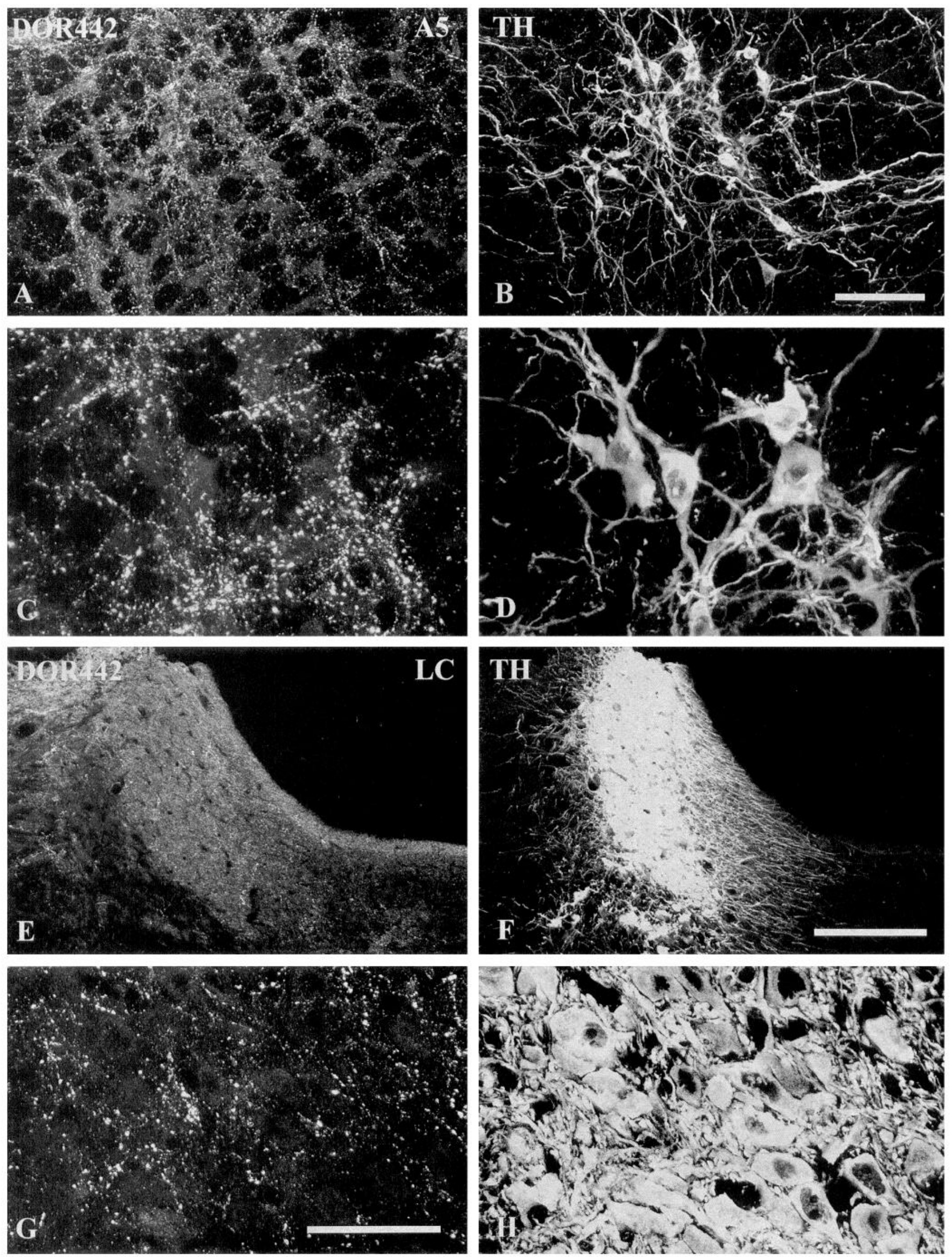


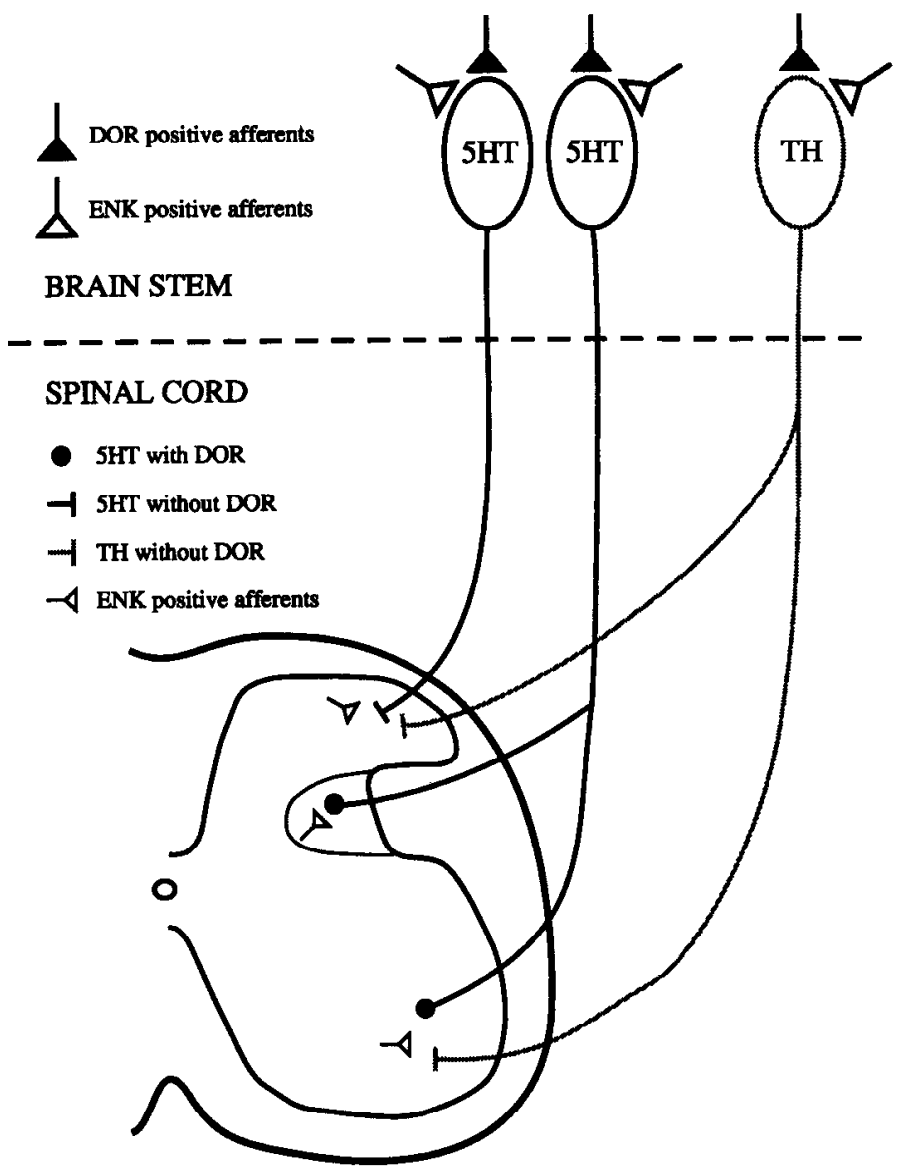

Figure 14. Schematic drawing illustrating the distribution of $\delta$-opioid receptors $(D O R)$ in relation to serotoninergic $(5 H T)$ and catecholaminergic $(T H)$ neurons and enkephalinergic $(E N K)$ terminals.

results in hypoalgesia (Dickenson et al., 1979; Levy and Proudfit, 1979; Azami et al., 1982; Jensen and Yaksh, 1986), suggesting that such receptors may be involved in mediation of analgesia. Similarly, electrophysiological studies have found evidence for $\kappa$-opioid receptors on glutamate-containing afferents to locus coeruleus (McFadzean et al., 1987; Pinnock, 1992), again suggesting that the function of brainstem aminergic neurons may be modulated by opioid receptors on their afferents. The source of the DOR-IR fibers observed in these brainstem regions is not known. However, nucleus raphe magnus receives afferent input from PAG and nucleus cuneformis (Mantyh and Peschanski, 1982; Fardin et al., 1984). In addition, small afferent projections to nucleus raphe magnus from cells located in the area of the laterodorsal tegmental nuclei have also been observed (Beitz et al., 1983; Fardin et al., 1984). Thus, it is tempting to speculate that the DORpositive cells seen in the laterodorsal tegmental nucleus and in PAG in part contribute to the afferent input to neurons in nucleus raphe magnus.

\section{Conclusion}

These results demonstrate that the antisera used in the present study recognize a $\delta$-opioid receptor primarily compartmentalized to axonal fibers and varicosities in both the spinal cord and brainstem. The present study is important in that it identifies with greatcr clarity than previous studics at least some of the transmitters whose release is likely to be regulated by ligands for $\delta$-opioid receptors in the brainstem and spinal cord. In our attempts to identify neurotransmitter systems expressing DOR it was found that the bulbospinal serotoninergic, but not the noradrenergic, system innervating lamina $\mathrm{V}$ of the dorsal horn and somatic motor nuclei contained DOR. The parent cell bodies for both of these biogenic amine systems in the brainstem were apposed by DOR-positive fibers. Comparing the distribution of enkephalin and DOR, complementary but not overlapping distribution was seen in many areas in the spinal cord and brainstem, and thus it appears that an endogenous ligand for DOR is present in the close vicinity of the receptor. The subcellular location of DOR suggests that it in most cases functions as a presynaptic receptor. Thus, it seems that DOR has the potential to modify/regulate neurotransmission in a variety of ways, in particular by altering the release of transmitter from nerve terminals. Several studies suggest that opioid receptors in nerve terminals accomplish this action by inhibition of the $\mathrm{Ca}^{2+}$ channels responsible for transmitter release (Werz and MacDonald, 1983). Thus, it is likely that a close relationship exists between opioid receptors and $\mathrm{Ca}^{2+}$ channels at nerve terminals (North, 1993).

\section{References}

Arvidsson U. Cullheim S, Ulfhake B, Bennett GW, Fone KCF, Cuello AC, Verhofstad AAJ, Visser TJ, Hökfelt T (1990) 5-hydroxytryptamine, substance $\mathrm{P}$ and thyrotropin-releasing hormone in the adult cat spinal cord segment L7: immunohistochemical and chemical studies. Synapse 6:237-270.

Arvidsson U, Cullheim S, Ulfhake B, Ramírez V, Dagerlind A, Luppi P-H, Kitahama K, Jouvet M, Terenius L, Åman K, IIökfelt T (1992) Distribution of enkephalin and its relation to serotonin in cat and monkey spinal cord and brain stem. Synapse 11:85-104.

Atweh SF, Kuhar MJ (1977a) Autoradiographic localization of opiate receptors in the rat brain. I. Spinal cord and lower medulla. Brain Res 124:53-67.

Atweh SF, Kuhar MJ (1977b) Autoradiographic localization of opiate receptors in rat brain. II. The brain stem. Brain Res 129:1-12.

Azami J, Llewelyn MB, Roberts MH (1982) The contribution of nucleus reticularis paragigantocellularis and nucleus raphe magnus to the analgesia produced by systemically administered morphine, investigated with the microinjection technique. Pain 12:229-246.

Basbaum AI, Fields HL (1984) Endogenous pain control systems: brainstem spinal pathways and endorphin circuitry. Annu Rev Neurosci 7:309-338.

Beitz AJ, Mullett MA, Weiner LL (1983) The periaqueductal gray projections to the rat spinal trigeminal, raphe magnus, gigantocellular pars alpha and paragigantocellular nuclei arise from separate neurons. Brain Res 288:307-314.

Besse D, Lombard MC, Besson JM (1991) Autoradiographic distribution of $\mu, \delta$ and $\kappa$ opioid binding sites in the superficial dorsal horn, over the rostrocaudal axis of the rat spinal cord. Brain Res 548: $287-291$.

Figure 13. Confocal microscopic images from rat brainstem after double labeling with rabbit $\delta$-opioid receptor (DOR) 442 and sheep tyrosine hydroxylase $(T H)$ antisera. $A-D$. Section from the brainstem including the lateral tegmental group (A5 according to Dahlström and Fuxe, 1964). A relatively dense network of DOR-positive fibers is seen around the TH-positive A5 neurons. $C$ and $D$ are higher-magnification images from $A$ and $B$, respectively. $E-H$, In the locus coeruleus $(L C)$ a less dense innervation of DOR-immunoreactive fibers is seen around TH-positive cells as compared to A5 neurons. $G$ and $H$ are close-ups from $E$ and $F$, respectively. Scale bars: $A$ and $B, 100 \mu \mathrm{m} ; C$ and $D, G$ and $H, 50 \mu \mathrm{m} ; E$ and $F$, $250 \mu \mathrm{m}$. 
Bineau-Thuroote M, Godefroy F, Weil-Fugazza J, Besson J-M (1984) The effect of morphine on the potassium evoked release of tritiated 5 -hydroxytryptamine from spinal cord slices in the rat. Brain Res 291:293-299.

Brase DA (1979) Roles of serotonin and $\gamma$-aminobutyric acid in opioid effects. In: Advances in biochemical psychopharmacology, Neurochemical mechanisms of opiates and endorphins (Loh HH, Ross DH, eds), pp 409-428. New York: Raven.

Brelje TC, Wessendorf MW, Sorenson RL (1993) Multicolor laser scanning confocal immunofluorescence microscopy: practical application and limitations. Methods Cell Biol 38:97-181.

Bzdega T, Chin H, Kim H, Jung HH, Kozak CA, Klee WA (1993) Regional expression and chromosomal localization of the $\delta$ opiate receptor gene. Proc Natl Acad Sci USA 90:9305-9309.

Carr FE, Reid AH, Wessendorf MW (1993) A cryptic peptide from the preprothyrotropin-releasing hormone precursor stimulates thyrotropin gene expression. Endocrinology 133:809-814.

Charnay Y, Leger L, Dray F, Berod A, Jouvet M, Pujol JF, Dubois PM (1982) Evidence for the presence of enkephalin in catecholaminergic neurones of cat locus coeruleus. Neurosci Lett 30:147-151.

Chen Y, Mestek A, Liu J, Hurley JA, Yu L (1993a) Molecular cloning and functional expression of a mu-opioid receptor from rat brain. Mol Pharmacol 44:8-12.

Chen Y, Mestek A, Yu L (1993b) Molecular cloning of a rat kappa opioid receptor reveals sequence similarities to the mu and delta opioid receptors. Biochem J 295:625-628.

Collin E, Bourgoin S, Chantrel D, Benoliel JJ, Mauborgne A, Hamon M, Cesselin F (1991) Presynaptic autoreceptors may control the release of met-enkephalin from the rat spinal cord. Adv Biosci 82:105106.

Coons AH (1958) Fluorescent antibody methods. In: General cytochemical methods (Danielli JF, ed), pp 399-422. New York: Academic.

Corbett AD, Paterson SJ, Kosterlitz. HW (1993) Selectivity of ligands for opioid receptors. In: Handbook of experimental pharmacology, Opioids I (Herz A, ed), pp 645-679. Berlin: Springer.

Dado RJ, Law PY, Loh HH, Elde R (1993) Immunofluorescent identification of a delta ( $\delta$ )-opioid receptor on primary afferent nerve terminals. Neuroreport 5:341-344.

Dahlström A, Fuxe K (1964) Evidence for the existence of monoamine neurons in the central nervous system. I. Demonstration of monoamines in cell bodies of brain stem neurons. Acta Physiol Scand 62: $1-55$.

Davila-Garcia MI, Azmitia EC (1989) Effects of acute and chronic administration of Leu-enkephalin on cultured serotonergic neurons: evidence for opioids as inhibitory neuronal growth factors. Dev Brain Res 49:97-103.

Delay-Goyet P, Zajac J-M, Roques BP (1990) Improved quantitative radioautngraphy of rat brain $\delta$-opioid binding sites using $\left[{ }^{3} \mathrm{H}\right]$ DSTBULET, a new highly potent and selective linear enkephalin analogue. Neurochem Int 16:341-368.

Dickenson AH, Oliveras JL, Besson JM (1979) Role of the nucleus raphe magnus in opiate analgesia as studied by the microinjection technique in the rat. Brain Res 170:95-111.

Elde R, Hökfelt T (1993) Coexistence of opioid peptides with other neurotransmitters. In: Handbook of experimental pharmacology, Opioids I (Herz A, ed), pp 585-624. Berlin: Springer.

Elde R, Hökfelt T, Johansson O, Terenius L (1976) Immunohistochemical studies using antibodies to leucine-enkephalin: initial observation on the nervous system of the rat. Neuroscience 1:349-351.

Evans CJ, Keith DJ Jr, Morrison H, Magendzo K, Edwards RH (1992) Cloning of a delta opioid receptor by functional expression. Science 258:1952-1955.

Fardin V, Oliveras JL, Besson JM (1984) Projections from the periaqueductal gray matter to the B3 cellular area (nucleus raphe magnus and nucleus reticularis paragigantocellularis) as revealed by the retrograde transport of horseradish peroxidase in the rat. J Comp Neurol 223:483-500.

Fukuda K, Kato S, Mori K, Nishi M, Takeshima H (1993) Primary structures and expression from cDNAs of rat opioid receptor deltaand mu-subtypes. FEBS Lett 327:311-314.

Fuxe K, Agnati LF, eds (1991) Advance in neuroscience, Transmission in the brain: novel mechanisms for neuronal transmission. New York: Raven.

Giesler G Jr, Elde RP (1985) Immunocytochemical studies of the pep- tidergic content of fibers and terminals within the lateral spinal and lateral cervical nuclei. J Neurosci 5:1833-1811.

Gouarderes C, Cros J, Quirion R (1985) Autoradiographic localization of mu, delta and kappa opioid receptor binding sites in rat and guinea pig spinal cord. Neuropeptides 6:331-342.

Gouarderes C, Tellez S, Tafani JAM, Zajac J-M (1993) Quantitative autoradiographic mapping of delta-opioid receptors in the rat central nervous system using [125]][D.Ala $\left.{ }^{2}\right]$ deltophin-I. Synapse 13:231-240.

Hagan RM, Hughes IE (1984) Opioid receptor sub-types involved in the control of transmitter release in cortex of the brain of the rat. Neuropharmacology 23:491-495.

Hartman BK, Zide D, Udenfriend S (1972) The use of dopamine $\beta$-hydroxylase as a marker for the noradrenergic pathways of the central nervous system in the rat. Proc Natl Acad Sci USA 69:2722-2726.

Herkenham M (1987) Mismatches between neurotransmitters and receptor localization in brain: obscrvations and implications. Ncuroscience 23:1-38.

Hökfelt T, Fuxe K, Goldstein M, Joh TH (1973) Immunohistochemical localization of three catecholamine synthesizing enzymes: aspects on methodology. Histochemie 33:231-254.

Illes P (1989) Modulation of transmitter and hormone release by multiple neuronal opioid receptors. Rev Physiol Biochem Pharmacol 112: 139-233.

Jensen TS, Yaksh TL (1986) Comparison of antinociceptive action of morphine in the periaqueductal gray, medial and paramedial medulla in rat. Brain Res 363:99-113.

Johnson DG, de C Nogueria Araujo GM (1981) A simple method of reducing the fading of immunofluorescence during microscopy. J Immunol Methods 43:349-350.

Khachaturian H, Watson SJ (1982) Some perspectives on monuanineopioid peptide interaction in rat central nervous system. Brain Res Bull 9:441-462.

Khachaturian H, Schäfer MKH, Lewis ME (1993) Anatomy and function of the endogenous opioid systems. In: Handbook of experimental pharmacology, Opioids I (Herz A, ed), pp 471-497. Berlin: Springer.

Kieffer BL, Befort K, Gaveriaux-Ruff C, Hirth CG (1992) The $\delta$-opioid receptor: isolation of a cDNA by expression cloning and pharmacological characterization. Proc Natl Acad Sci USA 89:1204812052.

Laduron PM, Castel MN (1990) Axonal transport of receptors. A major criterion for presynaptic localization. Ann NY Acad Sci 604:462469.

Levy RA, Proudfit HK (1979) Analgesia produced by microinjection of baclofen and morphine at brain stem sites. Eur J Pharmacol 57: 43-55.

Liu H, Brown JL, Jasmin L, Maggio JE, Vigna SR, Mantyh PW, Basbaum AI (1994) Synaptic relationship between substance P and the substance $P$ receptor: light and electron microscopic characterization of the mismatch between neuropeptides and their receptors. Proc Natl Acad Sci USA 91:1009-1013.

Lubetzki C, Chesselet MF, Glowinski J (1982) Modulation of dopamine release in rat striatal slices by delta opiate agonists. J Pharmacol Exp Ther 222:435-440.

Mansour A, Watson SJ (1993) Anatomical distribution of opioid receptors in mammalians: an overview. In: Handbook of experimental pharmacology, Opioids I (Herz A, ed), pp 79-102. Berlin: Springer.

Mansour A, Khachaturian H, Lewis ME, Akil H, Watson SJ (1987) Autoradiographic differentiation of mu, delta, and kappa opioid receptors in the rat forebrain and midbrain. J Neurosci 7:2445-2464.

Mansour A, Thompson RC, Akil H, Watson SJ (1993) Delta opioid receptor mRNA distribution in the brain: comparison to delta receptor binding and proenkephalin mRNA. J Chem Neuroanat 6:351-362.

Mantyh PW, Peschanski M (1982) Spinal projections from the periaqueductal grey and dorsal raphe in the rat, cat and monkey. Neuroscience 7:2769-2776

McFadzean I, Lacey MG, IIill RG, IJenderson G (1987) Kappa opioid receptor activation depresses excitatory synaptic input to rat locus coeruleus neurons in vitro. Neuroscience 20:231-239.

Menetrey D, Giesler GJ Jr, Besson JM (1977) An analysis of response properties of spinal cord dorsal horn neurones to nonnoxious and noxious stimuli in the spinal cord. Exp Brain Res 27:15-33.

Meng F, Xie GX, Thompson RC, Mansour A, Goldstein A, Watson SJ, Akil H (1993) Cloning and pharmacological characterization of a rat kappa opioid receptor. Proc Natl Acad Sci USA 90:9954-9958.

Mesce KA, Klukas KA, Brelje TC (1993) Improvements for the ana- 
tomical characterization of insect neurons in whole mount: the use of cyanine-derived fluorophores and laser scanning confocal microscopy. Cell Tissue Res 271:381-397.

Millhorn DE, Hökfelt T, Verhofstad AAJ, Terenius L (1989) Individual cells in the raphe nuclei of the medulla oblongata in the rat that contain immunoreactivities for both serotonin and enkephalin project to the spinal cord. Exp Brain Res 75:536-542.

Minami M, Toya T, Katao Y, Maekawa K, Nakamura S, Onogi T, Kaneko S, Satoh M (1993) Cloning and expression of a cDNA for the rat kappa-opioid receptor. FEBS Lett 329:291-295.

Monroe PJ, Michaux K, Smith DJ (1986) Evaluation of the direct actions of drugs with a serotoninergic link in spinal analgesia on the release of ${ }^{3}$ Hserotonin from spinal cord synaptosomes. Neuropharmacology 25:261-265.

Morris BJ, Herz A (1987) Distinct distribution of opioid receptor types in rat lumbar spinal cord. Naunyn Schmiedebergs Arch Pharmacol 336:240-243.

Mulder AH, Schoffelmeer ANM (1993) Multiple opioid receptors and presynaptic modulation of neurotransmitter release in the brain. In: Handbook of experimental pharmacology, Opioids I (Herz A, ed), pp 125-144. Berlin: Springer.

Nishi M, Takeshima H, Fukuda K, Kato S, Mori K (1993) cDNA cloning and pharmacological characterization of an opioid receptor with high affinities for kappa-subtype-selective ligands. FEBS Lett 330:77-80.

North RA (1993) Opioid actions on membrane ion channels. In: Handbook of experimental pharmacology, Opioids I (Herz A, ed), pp 773 797. Berlin: Springer.

Pan ZZ, Williams JT, Osborne P (1990) Opioid actions on single nucleus raphe magnus neurons from rat and guinea pig in vitro. J Physiol (Lond) 427:5 19-532.

Pan ZZ, Wessendorf MW, Williams JT (1993) Modulation by serotonin of the neurons in rat nucleus raphe magnus in vitro. Neuroscience $54: 421-429$.

Parenti M, Tirone F, Olgiati VR, Groppetti A (1983) Presence of opiate receptors on striatal serotoninergic nerve terminals. Brain Res 280 : 317-322.

Pasquini F, Bochet P, Garbay-Jaureguiberry C, Roques BP, Rossier J, Beaudet A (1992) Electron microscopic localization of photoaffinitylabelled delta opioid receptors in the neostriatum of the rat. J Comp Neurol 326:229-244.

Pasternak GW (1988) The opiate receptors. New Jersey: Humana.

Paxinos G, Watson C (1986) The rat brain in stereotaxic coordinates New York: Academic.

Petit F, Hamon M, Fournie ZM, Roques BP, Glowinski J (1986) Further evidence for a role of delta-opiate receptors in the presynaptic regulation of newly synthesized dopamine release. Eur J Pharmacol 126: $1-9$.

Pinnock RD (1992) A highly selective kappa-opioid receptor agonist, CI-977, reduces excitatory synaptic potentials in the rat locus coeruleus in vitro. Neuroscience 47:87-94.

Platt JL, Michael $\Lambda F$ (1983) Retardation of fading and enhancement of intensity of immunofluorescence by p-paraphenylenediamine. $\mathbf{J}$ Histochem Cytochem 31:840-842.

Satoh K, Fibiger HC (1986) Cholinergic neurons of the laterodorsal tegmental nucleus: efferent and afferent connections. J Comp Neurol 253:277-302.

Scheller RH, Hall ZW (1992) Chemical messengers at synapses. In: An introduction to molecular neurobiology (Hall ZW, ed), pp 119 147. Sunderland, MA: Sinauer.

Sharif NA, Hughes J (1989) Discrete mapping of brain mu and delta opioid receptors using selective peptides: quantitative autoradiography, species differences and comparison with kappa receptors. Peptides 10:499-522.

Shigemoto R, Nakaya Y, Nomura S, Ogawa-Meguro R, Ohishi H, Kaneko T, Nakanishi S, Mizuno N (1993) Immunocytochemical localization of rat substance $P$ receptor in the striatum. Neurosci Lett 153: $157-160$

Sofuoglu M, Portoghese PS, Takemori AE (1991) Differential antagonism of delta opioid agonists by naltrindole and its benzofuran an- alogue (NTB) in mice: evidence for delta opioid receptor subtypes. J Pharmacol Exp Ther 257:676-680.

Staines WA, Meister B, Melander T, Nagy JI, Hökfelt T (1988) Threecolor immunofluorescence histochemistry allowing triple labelling within a single section. J Histochem Cytochem 36:145-151.

Starke K (1981) Presynaptic receptors. Annu Rev Pharmacol Toxicol 21:7-30.

Stevens CW, Lacey CB, Miller KE, Elde RP, Seybold VS (1991) Biochemical characterization and regional quantification of mu, delta and kappa opioid binding sites in rat spinal cord. Brain Res 550:77-85.

Tashiro T, Satoda T, Takahashi O, Matsushima R, Mizuno N (1988) Distribution of axons exhibiting both enkephalin- and serotonin-like immunoreactivities in the lumbar cord segments: an immunohistochemical study in the cat. Brain Res 440:357-362.

Thompson RC, Mansour A, Akil H, Watson SJ (1993) Cloning and pharmacological characterization of a rat mu opioid receptor. Neuron 11:903-913.

Tramu G, Pillez A, Leonardelli J (1978) An efficient method of antibody elution for the successive or simultaneous localization of two antigens by immunocytochemistry. J Histochem Cytochem 26:322324.

Vigna SR, Bowden JJ, McDonald DM, Fisher J, Okamoto A, McVey DC, Payan DG, Bunnett NW (1994) Characterization of antibodies to the rat substance $\mathrm{P}(\mathrm{NK}-1)$ receptor and to a chimeric substance $P$ receptor expressed in mammalian cells. J Neurosci 14:834-845.

Vincent SR, Satoh K, Armstrong DM, Fibiger HC (1983) Substance P in the ascending cholinergic reticular system. Nature 306:688-691.

Waksman G, Hamel E, Fournie-Zaluski MC, Roques BP (1986) Comparative distribution of the neutral endopeptidase "enkephalinase" and $\mu$ and $\delta$ opioid receptors in rat brain by autoradiography. Proc Natl Acad Sci USA 83:1523-1527.

Wang BR, Senba E, Tohyama M (1989) Ultrastructural investigation of substance $\mathrm{P}$-, leucine-enkephalin- and 5-hydroxytryptamine-like immunoreactive terminals in the area of cremaster motoneurons of the male rat. Neuroscience 28:711-723.

Werling LL, Brown SR, Cox BM (1987) Opioid receptor regulation of the release of norepinephrine in brain. Neuropharmacology 26:987996.

Werz MA, MacDonald RL (1983) Opioid peptides selective for muand delta-opiate receptors reduce calcium-dependent action potential duration by increasing potassium conductance. Neurosci Lett 42:173178 .

Wessendorf MW, Brelje TC (1993) Multicolor fluorescence microscopy using the laser-scanning confocal microscope. Neuroprotocols 2:121140 .

Wessendorf MW, Elde RP (1985) Characterization of an immunofluorescence technique for the demonstration of coexisting neurotransmitters within nerve fibers and terminals. J Histochem Cytochem 33: 984-994.

Wessendorf MW, Apple NM, Molitor TW, Elde RP (1990) A method for immunofluorescent demonstration of three coexisting neurotransmitters in rat brain and spinal cord, using the fluorophores fluorescein, lissamine rhodamine, and 7-amino-4-methylcoumarin-3-acetic acid. $\mathbf{J}$ Histochem Cytochem 38:1859-1877.

Willcockson WS, Chung JM, Hori Y, Lee KH, Willis WD (1984) Effects of iontophorctically released amino acids and amines on primate spinothalamic tract cells. J Neurosci 4:732-740.

Yasuda K, Raynor K, Kong H, Breder CD, Takeda J, Reisine T, Bell GI (1993) Cloning and functional comparison of $\kappa$ and $\delta$ opioid receptors from mouse brain. Proc Natl Acad Sci USA 90:6736-6740.

Young WSI, Wamsley JK, Zarbin MA, Kuhar MJ (1980) Opioid receptors undergo axonal flow. Science 210:76-78.

Zajac J-M, Peschanski M, Besson J-M, Roques BP (1988) High-resolution autoradiography of opioid receptors and enkephalinase in the rat spinal cord. In: Pain research and clinical management (Dubner R, Gebhard GF, Bond MR, eds), pp 436-441. Amsterdam: Elsevier.

Zajac J-M, Lombard M-C, Peschanski M, Besson J-M, Roques BP (1989) Autoradiographic study of $\mu$ and $\delta$ opioid binding sites and neutral endopeptidase-24.11 in rat after dorsal root rhizotomy. Brain Res 477:400-403.

Zamboni L, De Martino C (1967) Buffered picric acid formaldehyde, a new rapid fixative for electron microscopy. J Cell Biol 35:148A. 